\title{
Teacher Compensation:
}

\section{Standard Practices and Changes in Wisconsin}

\section{WCER Working Paper No. 2016-5}

August 2016

Steven M. Kimball, Ph.D., Herbert G. Heneman, III, Ph.D., Robin Worth, Ph.D., Jessica Arrigoni, and Daniel Marlin

Wisconsin Center for Education Research

University of Wisconsin-Madison

steven.kimball@wisc.edu 


\section{Teacher Compensation: Standard Practices and Changes in Wisconsin}

\section{Steve Kimball, Herb Heneman, Robin Worth, Jessica Arrigoni, and Dan Marlin}

Over many decades, teachers' compensation has been determined through standard practices, commonly represented by the single salary schedule. While these practices served districts well in a number of respects, many argue that new forms of teacher pay could provide powerful levers for changing teacher performance and improving student achievement by enhancing recruitment, development, and retention efforts for effective educators (Committee for Economic Development, 2009; Odden \& Kelley, 2002; Odden \& Wallace, 2008; TNTP, 2014).

Historically, experiments with alternative compensation programs have been rare or episodic. Notable reforms included Kentucky's school-based performance award program, the CharlotteMecklenburg, North Carolina, school-based performance award program, and the Los Angeles Vaughan charter school knowledge and skills-based compensation system. ${ }^{1}$ Multiple school systems in several states implemented the National Institute for Excellence in Teaching's teacher career management and compensation program known as the TAP System. The welldocumented Denver ProComp system also involved a broad compensation and associated career management program restructuring.

To encourage broader experimentation with compensation and human resource reforms, the U.S. Department of Education administered the Teacher Incentive Fund, in which states and districts competed for millions of dollars in grants to implement new performance-based forms of teacher pay in high-need schools (U.S. Department of Education, 2016, July 18). Additionally, the Race to the Top program (U.S. Department of Education, 2016, June 6) embraced an improvement agenda that included uses of new educator effectiveness measures to support professional growth, and educational equity and accountability goals. As a result, the prevalence and pace of compensation reform has increased nationally.

Many Wisconsin school districts initiated their own teacher pay design and delivery transformations following the passage of Wisconsin Act 10 in 2011 (Beck, 2014; Mendez, 2014; Richards, 2012, August 19; Richards, 2012, November 22). Act 10 eliminated collective bargaining rights for most public employees, retained teacher compensation bargaining only for base pay increases, and limited that bargaining to the percentage change in the consumer price index (Wisconsin Act 10, 2011). With new flexibility at their disposal, and an undercurrent comprising many national compensation experiments, Wisconsin districts have begun moving away from standard compensation practices. Although pay changes are the focus of state media coverage, there are few information sources about the variety and scope of Wisconsin compensation revisions.

\footnotetext{
${ }^{1}$ For more information, see early studies on teacher compensation experimentation at http://cpre.wceruw.org/ecomp/products.php.
} 
In this paper, we first provide an overview of two standard compensation practices that are common around the United States. We include terminology and exhibits that illustrate the basics of such practices. We then summarize seven major types of compensation reform initiatives that are being undertaken throughout the country. The focus next turns to Wisconsin district teacher compensation reform initiatives. We describe key findings obtained from interviews with Wisconsin district leaders, along with our review of compensation-related district documents. We situate our findings within standard compensation practice to illustrate where and how much Wisconsin compensation practices have changed. The paper concludes with key questions districts should consider as they revise pay systems or reflect on pay changes.

\section{Standard Teacher Compensation Practices}

\section{Single Salary Schedule}

The single salary schedule, also referred to as the "steps and lanes” schedule, is a standard way of determining and delivering teacher pay throughout the country. Exhibit 1 shows a typical single salary schedule, with 30 steps on the left side and seven lanes across the top. Each step represents a year of service (seniority) in the district. The lanes represent increasing levels of educational attainment in the form of degrees (bachelor's, master's, doctorate), and additional completed academic course credits $(15,30,45)$. A teacher's salary (also known as base pay) is determined by locating the appropriate cell (years of service and level of education) for a given teacher. A teacher's base pay increase may come about in two ways. First, the entire schedule may be increased, such as applying a $2 \%$ increase to the amounts in the cells. Second, the teacher may receive a raise for additional seniority or education.

Exhibit 1: Example of a Single Salary (Steps and Lanes) Schedule

\begin{tabular}{|ccccccccc|}
\hline $\begin{array}{c}\text { Years } \\
\text { of } \\
\text { Service }\end{array}$ & $\begin{array}{c}\text { Bachelor } \\
\text { of Arts }\end{array}$ & $\begin{array}{c}\text { Bachelor } \\
\text { of Arts }\end{array}$ & $\begin{array}{c}\text { Bachelor } \\
\text { of Arts }\end{array}$ & $\mathbf{3 0}$ & $\begin{array}{c}\text { Master } \\
\text { of Arts }\end{array}$ & $\begin{array}{c}\text { Master } \\
\text { of Arts }\end{array}$ & $\begin{array}{c}\text { Master } \\
\text { of Arts }\end{array}$ & $\begin{array}{c}\text { Master of } \\
\text { Arts 60/ } \\
\text { Doctorate }\end{array}$ \\
\hline $\mathbf{0}$ & $\$ 28,000$ & $\$ 29,400$ & $\$ 30,870$ & $\$ 32,414$ & $\$ 34,034$ & $\$ 35,736$ & $\$ 37,523$ \\
$\mathbf{1}$ & $\$ 28,560$ & $\$ 29,988$ & $\$ 31,487$ & $\$ 33,062$ & $\$ 34,715$ & $\$ 36,451$ & $\$ 38,273$ \\
$\mathbf{2}$ & $\$ 29,131$ & $\$ 30,588$ & $\$ 32,117$ & $\$ 33,723$ & $\$ 35,409$ & $\$ 37,180$ & $\$ 39,039$ \\
$\mathbf{3}$ & $\$ 29,714$ & $\$ 31,200$ & $\$ 32,759$ & $\$ 34,397$ & $\$ 36,117$ & $\$ 37,923$ & $\$ 39,819$ \\
$\mathbf{4}$ & $\$ 30,308$ & $\$ 31,824$ & $\$ 33,415$ & $\$ 35,085$ & $\$ 36,840$ & $\$ 38,682$ & $\$ 40,616$ \\
$\mathbf{5}$ & $\$ 30,914$ & $\$ 32,460$ & $\$ 34,083$ & $\$ 35,787$ & $\$ 37,576$ & $\$ 39,455$ & $\$ 41,428$ \\
$\mathbf{6}$ & $\$ 31,533$ & $\$ 33,109$ & $\$ 34,765$ & $\$ 36,503$ & $\$ 38,328$ & $\$ 40,244$ & $\$ 42,257$ \\
$\mathbf{7}$ & $\$ 32,163$ & $\$ 33,771$ & $\$ 35,460$ & $\$ 37,233$ & $\$ 39,095$ & $\$ 41,049$ & $\$ 43,102$ \\
$\mathbf{8}$ & $\$ 32,806$ & $\$ 34,447$ & $\$ 36,169$ & $\$ 37,978$ & $\$ 39,876$ & $\$ 41,870$ & $\$ 43,964$ \\
$\mathbf{9}$ & $\$ 33,463$ & $\$ 35,136$ & $\$ 36,893$ & $\$ 38,737$ & $\$ 40,674$ & $\$ 42,708$ & $\$ 44,843$ \\
$\mathbf{1 0}$ & $\$ 34,132$ & $\$ 35,838$ & $\$ 37,630$ & $\$ 39,512$ & $\$ 41,487$ & $\$ 43,562$ & $\$ 45,740$ \\
$\mathbf{1 1}$ & $\$ 34,814$ & $\$ 36,555$ & $\$ 38,383$ & $\$ 40,302$ & $\$ 42,317$ & $\$ 44,433$ & $\$ 46,655$ \\
$\mathbf{1 2}$ & $\$ 35,511$ & $\$ 37,286$ & $\$ 39,151$ & $\$ 41,108$ & $\$ 43,164$ & $\$ 45,322$ & $\$ 47,588$ \\
$\mathbf{1 3}$ & $\$ 36,221$ & $\$ 38,032$ & $\$ 39,934$ & $\$ 41,930$ & $\$ 44,027$ & $\$ 46,228$ & $\$ 48,540$ \\
$\mathbf{1 4}$ & $\$ 36,945$ & $\$ 38,793$ & $\$ 40,732$ & $\$ 42,769$ & $\$ 44,907$ & $\$ 47,153$ & $\$ 49,510$ \\
\hline
\end{tabular}




\begin{tabular}{|c|c|c|c|c|c|c|c|}
\hline $\begin{array}{c}\text { Years } \\
\text { of } \\
\text { Service }\end{array}$ & $\begin{array}{c}\text { Bachelor } \\
\text { of Arts }\end{array}$ & $\begin{array}{c}\text { Bachelor } \\
\text { of Arts } \\
15 \\
\end{array}$ & $\begin{array}{c}\text { Bachelor } \\
\text { of Arts } \\
\mathbf{3 0} \\
\end{array}$ & $\begin{array}{l}\text { Master } \\
\text { of Arts }\end{array}$ & $\begin{array}{c}\text { Master } \\
\text { of Arts } \\
30 \\
\end{array}$ & $\begin{array}{c}\text { Master } \\
\text { of Arts } \\
45 \\
\end{array}$ & $\begin{array}{c}\text { Master of } \\
\text { Arts 60/ } \\
\text { Doctorate }\end{array}$ \\
\hline 15 & $\$ 37,684$ & $\$ 39,569$ & $\$ 41,547$ & $\$ 43,624$ & $\$ 45,806$ & $\$ 48,096$ & $\$ 50,501$ \\
\hline 16 & $\$ 38,438$ & $\$ 40,360$ & $\$ 42,378$ & $\$ 44,497$ & $\$ 46,722$ & $\$ 49,058$ & $\$ 51,511$ \\
\hline 17 & $\$ 39,207$ & $\$ 41,167$ & $\$ 43,225$ & $\$ 45,387$ & $\$ 47,656$ & $\$ 50,039$ & $\$ 52,541$ \\
\hline 18 & $\$ 39,991$ & $\$ 41,990$ & $\$ 44,090$ & $\$ 46,294$ & $\$ 48,609$ & $\$ 51,040$ & $\$ 53,592$ \\
\hline 19 & $\$ 40,791$ & $\$ 42,830$ & $\$ 44,972$ & $\$ 47,220$ & $\$ 49,581$ & $\$ 52,060$ & $\$ 54,663$ \\
\hline 20 & $\$ 41,607$ & $\$ 43,687$ & $\$ 45,871$ & $\$ 48,165$ & $\$ 50,573$ & $\$ 53,102$ & $\$ 55,757$ \\
\hline 21 & & $\$ 44,561$ & $\$ 46,789$ & $\$ 49,128$ & $\$ 51,584$ & $\$ 54,164$ & $\$ 56,872$ \\
\hline 22 & & $\$ 45,452$ & $\$ 47,724$ & $\$ 50,111$ & $\$ 52,616$ & $\$ 55,247$ & $\$ 58,009$ \\
\hline 23 & & $\$ 46,361$ & $\$ 48,679$ & $\$ 51,113$ & $\$ 53,668$ & $\$ 56,352$ & $\$ 59,169$ \\
\hline 24 & & $\$ 47,288$ & $\$ 49,652$ & $\$ 52,135$ & $\$ 54,742$ & $\$ 57,479$ & $\$ 60,353$ \\
\hline 25 & & $\$ 48,234$ & $\$ 50,646$ & $\$ 53,178$ & $\$ 55,837$ & $\$ 58,629$ & $\$ 61,560$ \\
\hline 26 & & $\$ 49,198$ & $\$ 51,658$ & $\$ 54,241$ & $\$ 56,953$ & $\$ 59,801$ & $\$ 62,791$ \\
\hline 27 & & $\$ 50,182$ & $\$ 52,692$ & $\$ 55,326$ & $\$ 58,092$ & $\$ 60,997$ & $\$ 64,047$ \\
\hline 28 & & $\$ 51,186$ & $\$ 53,745$ & $\$ 56,433$ & $\$ 59,254$ & $\$ 62,217$ & $\$ 65,328$ \\
\hline 29 & & $\$ 52,210$ & $\$ 54,820$ & $\$ 57,561$ & $\$ 60,439$ & $\$ 63,461$ & $\$ 66,634$ \\
\hline 30 & & $\$ 53,254$ & $\$ 55,917$ & $\$ 58,713$ & $\$ 61,648$ & $\$ 64,731$ & $\$ 67,967$ \\
\hline
\end{tabular}

\section{Salary Supplements}

Many districts provide additional pay to teachers via various supplements or "add-ons" to base pay. These are delivered as stipends or bonuses. Exhibit 2 shows the definitions of these two terms, along with examples of activities and accomplishments that may be rewarded. The use of salary supplements indicates district administrators believe many teacher actions beyond normal classroom instruction are worthy of pay in their own right.

\section{Exhibit 2: Examples of Supplements to Base Pay}

\begin{tabular}{|l|}
\hline Stipend \\
\hline Definition: An upfront addition to base pay that is not permanent. \\
\hline Examples of activities by which teachers can earn stipends: \\
- Leading extracurricular activities \\
- Playing expertise role (e.g., master teacher) \\
- Taking on administrative leadership role (e.g., department chair) \\
- Gaining special certification (e.g., National Board for Professional Teaching \\
\hline Bonus \\
\hline Definition: A one-time, after-the-fact payment not built into base pay. \\
Examples of bonuses: \\
- Hiring bonus \\
\hline
\end{tabular}


- Performance bonus for meeting performance targets such as a specific performance rating ("highly effective") or a student achievement goal (85\% of students in a class reach growth target)

- Bonus for teaching hard-to-staff subject or at hard-to-staff school

\section{Advantages and Disadvantages of Standard Pay Practices}

The single salary schedule offers several advantages. It treats teachers equitably on the basis of seniority and education, thus minimizing pay bias possibilities (e.g., favoritism, gender, and race). It has fairly mechanical rules (negotiation aside) for determining pay and pay increases, and it allows a teacher to view career progression in a known and predictable way. Teacher acceptance of the single salary schedule is typically very high because of these features, particularly among teachers with more seniority (Odden \& Kelley, 2002).

Criticisms include perception that the single salary schedule is too rigid, leaving districts little flexibility for compensation discretion in attracting, rewarding, and retaining teachers (Hanushek, 2007). Typical single salary schedules favor more experienced teachers because across-the-board pay increases are weighted toward teachers with more seniority. Moreover, primarily rewarding seniority and education is problematic since research findings question the impact of these factors on student performance (Odden, 2001; Protsik, 1995; Firestone, 1994). While predictable, career and pay progression is slow and does not allow newer teachers to leapfrog quickly into high pay based on their accomplishments or effectiveness. Finally, automatic step and lane pay increases lock in pay that a district may not be able to afford because of revenue decreases resulting from enrollment or other funding declines.

Turning to salary supplements, their major advantage is that they provide the district with needed compensation flexibility to encourage and reward many different school or district activities. But supplements often require qualitative assessments of teachers in terms of their eligibility and appointment. Educators and other stakeholder groups may question soundness and validity of such subjective assessments. To counter such contentions, districts must develop assessment systems, rules, and training for assessors, all of which require expertise and incur cost. Finally, though pay supplements are not permanent, outright elimination of pay supplement programs is difficult due to their "pay sweetener" status and organizational need for the awarded roles.

\section{Teacher Compensation Reforms}

Against the standard practice backdrop, districts across the country are developing many types of compensation reforms and programs. The following presents brief and generic highlights of seven such initiatives.

\section{Modification to the Single Salary Schedule}

Maintaining a commitment to the single salary schedule is possible while making changes to step and lane practices (see, for example, Heneman \& Kimball, 2008), as shown in Exhibit 3. 
Generally, step and lane changes are made to reduce the impact of seniority and education on base pay and pay increases, and to lessen the financial impact of automatic pay increases.

Exhibit 3: Modifications to the Single Salary Schedule

Changes to Steps
- Increase/decrease number of steps
- Change length of time between steps
- Create conditional step movement (e.g., the teacher must receive an "effective"
performance evaluation to receive a step increase)
Changes to Lanes
- Increase/decrease number of lanes
- Redefine lanes (e.g., to clarify what is an acceptable master's degree or what specific
- coursework will count)
Drop use of lanes

\section{Performance Pay}

Teacher performance pay encompasses a wide variety of specific types of pay plans. They share a common objective of trying to link pay increases to individual or schoolwide measures of teacher performance. Exhibit 4 represents performance measures and monetary payouts possible in teacher performance pay plans.

\section{Exhibit 4: Teacher Performance Pay}

\section{Individual Performance}

- Teacher evaluation ratings compared to performance standards

- Percentage of teacher's students meeting proficiency standard

- Percentage increase in students meeting proficiency standard

- Value-added test score gains by teacher's students

\section{Schoolwide Performance}

- Percentage of school's students meeting proficiency and/or growth measure

- Percentage increase in school's students meeting proficiency standard

- Schoolwide value-added measures for determining test score gains

- Graduation, attendance, advanced placement rates

\section{Payouts}

- Qualification for a step increase on single salary schedule

- Payout schedule for bonus

- Payout schedule for base pay increase

- Payout schedule based on combined performance measures

\section{Knowledge and Skills-Based Pay}

Also known as competency pay, knowledge and skills-based pay programs target specific knowledge and skills (competencies) to be rewarded. The teacher must acquire and demonstrate the competencies that have been identified as critical for teacher classroom or team performance 
or for other assignments. Payouts range from one-time bonuses to multi-year base pay increases. The latter must be re-earned after some time period. Examples are provided in Exhibit 5.

Exhibit 5: Teacher Knowledge and Skills-Based (Competency) Pay

\begin{tabular}{|c|c|}
\hline Knowledge/Skill & Payout \\
\hline $\begin{array}{l}\text { - Completion of new skill training (e.g., data } \\
\text { analysis and usage; instructional team } \\
\text { building) }\end{array}$ & - Bonus $\$ 750$ \\
\hline - Completion of instructional portfolio & - $\quad$ Bonus $\$ 1,200$ \\
\hline - Completion of specialist certification & - $\quad$ Base pay increase $\$ 1,500$ \\
\hline $\begin{array}{l}\text { - Completion of National Board for } \\
\text { Professional Teaching Standards certification }\end{array}$ & - $\quad$ Base pay increase $\$ 6,000$ \\
\hline
\end{tabular}

\section{Career Levels, Bands, Ladders}

These systems feature progressively higher base pay categories, such as apprentice teacher, novice teacher, career teacher, advanced teacher, and accomplished teacher. These replace the single salary schedule. There are defined criteria for each category, such as performance rating levels, educational attainment, years of teaching and additional roles served. There may also be step increases adding to base pay within each category, along with an indication of how long the teacher can remain in the category. There is often an implied "up or out” progression from Apprentice to the Career level. Refer to Exhibit 6 for an illustration of a pay (career) band.

Exhibit 6: Teacher Career Levels/Bands/Ladders

\begin{tabular}{|c|c|}
\hline Career Band & Qualifications \\
\hline $\begin{array}{l}\text { Accomplished } \\
\text { (no maximum years) }\end{array}$ & 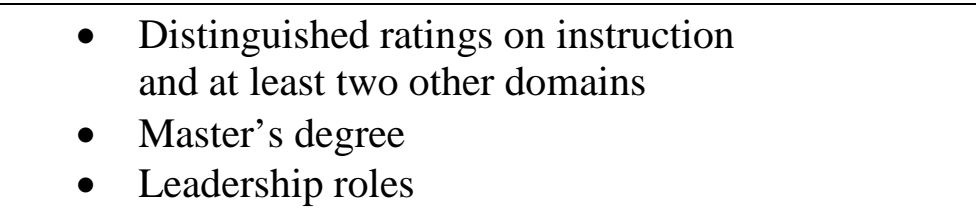 \\
\hline $\begin{array}{l}\text { Advanced } \\
\text { (no maximum years) }\end{array}$ & $\begin{array}{ll}\text { - } & \text { Distinguished ratings on instruction } \\
\text { and one other domain } \\
\text { - } \\
\text { - } \\
\text { - } & \text { At least proficient ratings on other domains } \\
\end{array}$ \\
\hline Career (no maximum years) & - Proficient on all domains \\
\hline Novice (5-year maximum) & - Mix of basic and proficient ratings on all domains \\
\hline Apprentice (2-year maximum) & $\begin{array}{ll}\text { - } & \text { Basic rating on all domains } \\
\text { - } & \text { Complete induction program }\end{array}$ \\
\hline
\end{tabular}

\section{Competitive Pay}

Competitive pay is used for attraction and retention purposes in response to labor market pressures. Bonuses or stipends are awarded beyond the normal base pay. Examples are shown in 
Exhibit 7. Situations in which to use competitive pay and pay amounts may be pre-determined or handled in a more ad hoc fashion by the principal or district administrator.

\section{Exhibit 7: Teacher Competitive Pay}

\section{A bonus or stipend is given for:}

- Attracting exceptionally qualified job candidates

- Teaching in a hard-to-staff school

- Teaching a hard-to-staff subject

- Retaining a valued teacher who has a job offer

\section{Pay for Leadership Roles}

Districts increasingly identify teachers to take on numerous new leadership roles. Districts may identify teachers to promote into roles or teachers may have to apply for these roles through formal selection processes. Stipends are usually paid while the teacher is in the role, which may be full or part time (which allows a teacher to remain in the classroom). Exhibit 8 shows types of leadership roles.

\section{Exhibit 8: Teacher Leadership Pay}

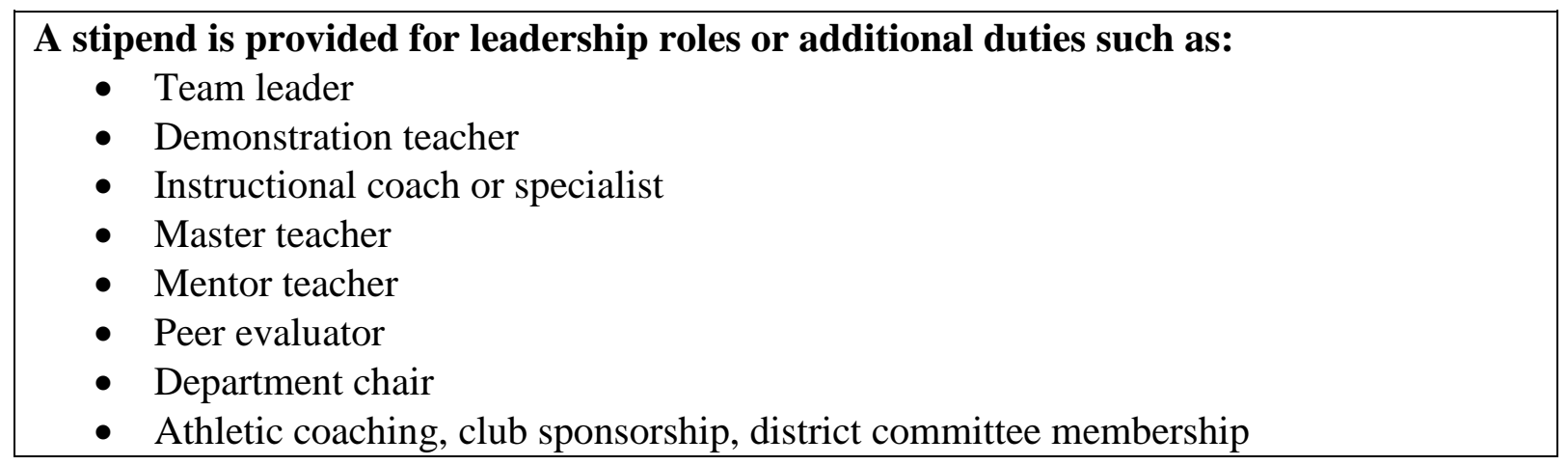

\section{Combined Plans}

The above plans can be combined or blended. A teacher performance pay plan, for example, could be combined with a teacher leadership plan, allowing teachers to be rewarded for both instructional and leadership success. In a more blended way, combined plans contain multiple components from other pay plans, including performance pay, seniority pay, and leadership role pay. Denver’s ProComp pay plan (Denver Public Schools, 2014) is a widely cited example of a highly developed combined plan.

\section{Wisconsin Study}

Interest in alternative compensation strategies existed in Wisconsin prior to the passage of Act 10 (Carlson, 2006; Ford, 2012), but the interest and pace of change in compensation practices across the state accelerated following enactment of this controversial law. While no data exist on the number of districts revising compensation strategies, media reports suggest widespread activity (Beck, 2014; Mendez, 2014; Richards, 2012, August 19; Richards, 2012, 
November 22; Taylor, 2015; Uhlig, 2014). This descriptive study fills a void in information about the types of compensation practices being implemented in school Wisconsin districts.

This study identifies and describes the types of compensation changes Wisconsin districts were considering or implementing as of December 2015. Although not exhaustive, the study indicates the wide variety of practices and current volatility relating to compensation for teaching roles. The review focuses on reasons for changing pay practices, the change process, modifications to the single salary schedule, and ways of determining base pay increases, bonus, and stipend pay. The findings provide information to districts, state policymakers and agencies, and professional associations about the nature of teacher compensation changes occurring within Wisconsin. They raise questions districts should consider about new compensation policies. We close the report with suggested material for additional reading about teacher compensation reform.

\section{Study Methodology}

We sought documentation, then interviewed leaders from 25 Wisconsin school districts we identified from news reports and word of mouth that were implementing or considering alternative compensation structures for their teachers. Multiple sources led to the districts identified for this study. First, the study team consulted the Wisconsin Association of School Boards for recommendations given its work with many districts around school board policy, including compensation reform. ${ }^{2}$ The association also provided website access to its compilation of teacher handbooks. Three study team members reviewed 50 handbooks to identify information related to compensation changes. The sample included every fifth handbook from a total of 269 handbooks accessed on the association site. To capture more recent compensation descriptions, we limited the review to handbooks dated 2013-14 or later. In most cases, the handbooks lacked information about compensation designs, but districts pursuing changes did tend to reference a change process or district board policy. We reviewed websites for those districts referencing compensation changes. Additionally, the team searched online media for any mentions of compensation changes in Wisconsin, which led us to include other districts in the study. Finally, the team sought recommendations from initial study participants for other districts they learned about during their compensation searches. Ultimately, 25 districts were included in the sample. See Appendix A for a list of participating districts.

We reviewed each district's website to obtain teacher compensation-related documents. Phone interviews were conducted with one leader in each district using a semi-structured protocol (see Appendix B). The questions pertained to the basic structure of prior compensation approaches; the impetus for pursuing compensation changes; the design features for the new base pay, bonus, and supplemental pay elements; performance pay approaches; and the design process. We asked district leaders what sources, if any, they used to inform their work (i.e., other models within Wisconsin or in other states) and for any other documents relating to their system

\footnotetext{
${ }^{2}$ We are grateful for the time and assistance provided by Barry Forbes of the Wisconsin Association of School Boards for this project and for the participation of district administrators who patiently answered our questions about their compensation policies.
} 
design that were not on the district website. Detailed notes were taken during the phone interviews, which averaged approximately 45 minutes in length.

The research team developed a basic template to summarize notes from the calls and document reviews. The template allowed the team to identify specific compensation features outlined earlier in this brief about compensation structures. Several team meetings were held to discuss themes emerging from reviews and plan for additional analysis. Each team member created analytical memos using the notes from interviews and district documents, focusing on the compensation structure elements and initial themes identified by the group. The study results are based on the cumulative evidence collected from these sources.

\section{Results}

Using the seven types of teacher compensation reforms outlined above, the paper next describes the variety of compensation changes initiated by the Wisconsin districts included in the study. First, the main themes relating to the impetus for the pay changes and the change process are summarized. Next, the compensation design elements are reported, along with illustrative examples.

Impetus for changes. Districts reported a variety of reasons for pursuing pay changes. Common themes involve fiscal concerns with prior systems, a desire to create compensation systems that embrace district goals and recognize teacher contributions to the organization, alignment with the Wisconsin Educator Effectiveness System, moving to a career pathway approach, the flexibility allowed by Act 10, and the increased pressure to compete with other districts for teaching talent.

Several districts sought to move away from automatic step increases or lane movement based on additional educational credits and advanced degrees. One district leader asserted that, "There was no connection between what we were paying people with advanced degrees and their output." Another administrator stated that, "the biggest driver was to find something more equitable and fair. Everyone agrees that basing compensation on years and degrees just doesn't make sense anymore.” These leaders, and others, want their compensation systems to embrace professional development opportunities more applicable to current roles as well as the performance expectations of the Wisconsin Educator Effectiveness System.

One district articulated the following multiple purposes for the new evaluation system:

- Ensure the district is able to attract and retain highly qualified professionals

- Establish clear and consistent definition of quality teaching

- Support professionals as they strive for teaching excellence

- Recognize contributions of professionals who are dedicated to advancing district goals

- Encourage professionals to experiment with innovative teaching methods to improve productivity and performance 
Finances and sustainability of new systems loomed large for almost all of the districts. Most respondents mentioned that instability and cuts to state aid rendered the prior salary schedules unsustainable before Act 10 . The new law allows flexibility to adjust compensation systems. School boards now have the ability to unilaterally change the salary structure or modify increases if finances become too prohibitive. With or without Act 10, however, given shrinking state education funding and enrollment changes in many districts, interviewees were clear that teacher compensation systems across the state were unstable.

Change process. Respondents mentioned that although Act 10 provided a means to pursue change, they were still concerned about the change process and how educators would react. Due to the sensitive nature and complexity of compensation reform, almost all districts formed compensation committees and engaged stakeholders in redesign. Districts varied, however, in the time involved with design planning and transition to the new plans, as well as the depth of involvement by teachers, administrators, and school board members. Despite the Act 10 allowance for districts to unilaterally change compensation structures, all of the districts involved teachers to some extent in planning, design, and implementation feedback. In only one district did it appear that the district administrator largely created the system with limited educator involvement.

Planning, design, and implementation proceeded differently in the districts. While some moved quickly with pay changes following Act 10 or were investigating changes prior to Act 10, others took more of a cautious approach to see what leading districts were doing and to learn from their first steps. The time from review of plan options to implementation ranged from one to three years. Some districts had formal committees that met regularly, while others had a limited design team that periodically sought feedback from educators and school leaders on design options. Many districts included school board members, and some included retired educators, teachers' association representatives, and occasionally outside consultants. Among consultants, Wisconsin Association of School Boards staff were most frequently referenced as helping provide background or facilitating the design.

Most districts engaged in a careful, and what appeared to be collaborative, approach to the design of the new compensation systems. For example, one district that focused heavily on communication used a survey at the front end to ask teachers what they wanted to see in a compensation system, frequently solicited feedback from stakeholders, provided updates on the district website, presented at board meetings, and held four design team meetings at each school.

Another district also pursued a very deliberate change process, with a compensation committee including seven teachers, one principal, three district leaders (including the superintendent), three school board members, and a consultant from Wisconsin Association of School Boards. The superintendent was deeply involved and compiled comprehensive, webbased resources that included meeting agendas, district model examples, and cost projections. The committee's goal was to design a compensation system that (a) aligned with the district mission and vision, (b) would promote professional learning, (c) would be financially feasible, 


\section{Teacher Compensation in Wisconsin}

and (d) would recognize rigor and relevance with professional evaluations. The district surveyed all teachers at the beginning stages to learn what they valued in a compensation system and used that information to inform proceedings. The district also gathered information on several other district models, carried out cost analyses of different options, and held about 12 structured meetings throughout the planning year to frame the system. The district intends to review the system quarterly.

No district found new funding to support the pay changes. Many indicated that the amount of payouts could change with funding shortfalls, but overall believed the funding amounts would be similar to their prior schedules. The tenuous nature of funding could contribute to educator unease with the financial security of promised pay adjustments and have an impact on retention.

The districts differed in regard to depth of planning and review of alternative compensation strategies. Administrators reported being aware of the compensation plans of neighboring districts and of pay comparisons, but some districts, such as the two noted above, extensively reviewed compensation approaches within the state and beyond. A few other districts appeared to develop their own approach with little research on alternative designs or compensation issues. Twelve districts involved outside consultants, with eight of those working with a Wisconsin Association of School Boards counsel to help facilitate planning or to provide input on compensation issues.

No districts reported having pilot tested their compensation plans, but most districts indicated that they will regularly review their systems and make any necessary adjustments.

Transition. Although the districts did not pilot test their new approaches, leaders expressed that the changes were intended to evolve over time, with adjustments made based on periodic review and reports by the design committee, district leadership, and the school board. Several districts reported being sensitive to issues typical of large scale educational change, including resistance among teachers and some school administrators, the need for clear and constant communication, time constraints in the design to implementation process, and transition challenges (i.e., making sure teachers were placed appropriately on the new salary schedule).

Districts took similar steps to transition teachers into the new system. All but one district moved teachers over in a way in which they did not lose salary. Placement in the new systems was often based on a level matching or slightly above current salary. Many added a sweetener by increasing all teachers' pay by a range of $\$ 500$ to $\$ 1,000$. Some offered across-the-board salary increases, such as one district that provided a $2 \%$ increase for all teachers. The transition process took careful planning. Adjustments were needed in several districts to make sure teachers were placed appropriately in the new schedules.

One district sought to hold teachers harmless in transition from the steps and lanes levels in the prior schedule to the new system using career levels, so they chose to extend the number of steps in the new schedule. This district's professional educator level, for example, now features 61 steps. Another district "red-circled" or "grandfathered" teachers who were making more than 
the maximum salary for their placement in the new schedule. Those teachers must re-earn performance stipends each year to maintain their prior pay level.

Modifications to salary structure. All of the districts previously used a single salary schedule based on steps and lanes. Each moved away from that structure to some degree. The districts limited the number of lanes or changed the lanes from education-based to a more careerlevel approach. All districts modified the steps.

Lane reductions. Most districts reduced the number of lanes and changed them from designations based on completion of higher education credits and degrees to other designations using career levels. As referenced above, several district leaders mentioned that research did not support the link between completion of higher education credits and degrees and more effective performance. Although some still recognized completion of master's degrees and district approved education credits, others dropped them completely from salary considerations.

Several districts have changed the salary structure so that newer educators can move up the salary schedule more quickly. These adjustments are in stark contrast to across-the-board increases under prior single salary schedule approaches, which favored senior educators regardless of performance.

Step modifications. In the past, step increases were granted for each year worked. Some districts in our sample increased the length of time for step increases (i.e., 2 to 3 years), while others maintained the annual step increase, but the step was conditional on "satisfactory" performance evaluation results or other factors. The definition of satisfactory evaluation results varies, but typically implies that there are no unsatisfactory ratings or that the educator is not on a plan of improvement. The step increase amount is often linked to the consumer price index.

Performance pay. Almost all districts administrators expressed an interest in tying compensation to performance, but only about a third had specific linkages between teacher performance measures and pay. Six used performance elements to determine placement in the salary schedule. Two had school-based performance bonuses. Only one district used classroomlevel student outcomes explicitly for performance pay.

Districts used a variety of ways to measure performance for pay decisions. Some reported rating performance using adapted measures from the Wisconsin Educator Effectiveness System. Northland Pines in the Eagle River area, for example, uses a knowledge and skills-based pay approach, based on an adapted version of the Cooperative Educational Service Agency 6 Effectiveness Project teacher evaluation rubric. Appendix $C$ includes an excerpt from the Northland Pines district's staff salary schedule. This district applies the locally adapted effectiveness rubric to assess a set of teaching evidence (referred to as an evidence log) that includes examples of professional practice and related teacher reflections. Principals review the evidence to make the performance judgment. Teachers are given a rating of 1 through 5 on each indicator. Level 5 is reserved for those who have master's degrees or national board certification. Scores are averaged across indicators with a range of 22-110. Each range has a corresponding 
pay level from $\$ 35,000$ for Level 1 to $\$ 64,263$ for Level 5. Unlike other districts in our sample, Northland Pines also allows for pay reductions if a teacher is placed lower on the new pay scale than on the prior scale or if a teacher receives an evaluation that places her or him at a lower level on the scale. The reduction is capped at $\$ 2,000$ per year until he or she reaches the pay amount associated with the lower rating. The pay can increase with improved performance ratings.

Neenah also bases salary level increases in part on performance determinations using the evaluation system. For example, a teacher in this district must receive all "effective" ratings on all standards in order to reach the third level of the salary schedule. To move to the next level, teachers must receive at least two "distinguished" and four "effective" ratings on the six standards. Movement to the higher levels also requires documented evidence of student learning gains, although the specific measures are not specified. The district's staff salary schedule is reproduced in Appendix D.

Another district using the state model evaluation approach uses a similar strategy, with level movement contingent on minimum evaluation ratings for each tier of its career level system as follows:

- Initial: no subdomain ratings at the unsatisfactory level

- Building: fewer than five subdomain ratings at the basic level; no ratings at the unsatisfactory level

- Professional: no subdomain ratings in the basic or unsatisfactory levels

- Advanced: all subdomain ratings at the proficient or distinguished levels; more than one subdomain rating at the distinguished level

- Exemplary: all subdomain ratings at the proficient or distinguished levels; more than five subdomain ratings at the distinguished level

In this district, principals also assess teacher-submitted portfolios to determine between-level and within-level advancement.

In contrast to the prior two examples, which base evaluation and resulting compensation decisions on evaluator (primarily principal) judgments, some districts use a panel (peer or peer and administrators) to review teaching portfolios during the year. In one district, contingent on satisfactory performance evaluation and peer review, teachers are eligible for \$2,000 salary increases following their summative evaluation year and $\$ 6,000$ increases every sixth year. Teachers with two or more unsatisfactory ratings on their evaluation are not eligible for salary increases.

Another district with a portfolio approach uses an administrator panel and a districtdeveloped rubric to initially place teachers on the new salary schedule. In subsequent years, a review panel made up of three administrators and three teachers reviews the teacher portfolios. The panel uses a review rubric to assess teachers on several dimensions, including evidence of satisfactory performance (at the early career stages) and evidence of advanced performance at the upper levels of the new pay schedule. 
In addition to other stipends, another district uses knowledge and skills assessments from the Wisconsin Educator Effectiveness System to determine bonuses. The district's two bonus levels are based on scores from the state model educator effectiveness measures of practice using domain scores from the state system’s Framework for Teaching. Level 1 provides a $\$ 2,500$ bonus and Level 2 provides a $\$ 1,000$ bonus. The bonuses are awarded during the fall following completion of summary (summative) evaluation years.

Almost all districts chose not to include classroom-level student outcomes for performance pay. The one district including student results awards small bonuses to advanced placement teachers whose students pass advance placement tests with scores of 3 or higher in the previous year. For example, if students meet the state average or greater, the teacher receives a $\$ 1,000$ bonus; $60 \%$ or greater, $\$ 500$ bonus; and 55\% or greater, $\$ 200$ bonus. Additionally, two districts used an adapted measure from the Wisconsin Educator Effectiveness System based on teacherdeveloped student learning objectives and professional practice goal attainment. ${ }^{3}$

Knowledge and skills-based pay. Our selected Wisconsin districts are experimenting with two main types of knowledge and skills-based pay. The first is based on a point system, where educators accumulate a set number of points related to professional development and other activities that are used to justify a pay increase as one-time stipends or points qualifying for a step or level movement. The second type relates to separate, district approved training, master's degrees and certifications, and national board certification.

Point systems are commonly used to substitute for what was previously automatic approval for lane movement based on accumulation of higher education credits and degrees. The new point systems include a mix of professional development training and/or leadership activities. Some districts have created extensive opportunities, including teacher-created options, while others list a limited set of options. Whether extensive or limited, these point systems represent the knowledge and skills the districts value. In some instances, teachers can choose their own professional learning activities, but must submit a request for approval before the district will allow the activity to count in the point system.

As reflected in Appendix E, the School District of the Menominee Area identified 35 professional point options, with four categories ranging from 5-point activities to 50-point activities. These points depend on the intensity/complexity of the training or professional activity. To illustrate, these activities include acting as a non-paid community education course instructor (5 points), taking a graduate course with prior approval (10 points/credit hour), participating on the building leadership team (25 points), and acting as a district trainer

\footnotetext{
${ }^{3}$ Student learning objectives in Wisconsin are key measures used in the state Educator Effectiveness System. Student learning objectives represent student growth targets, related instructional practices, and student outcome assessments that are teacher-identified and informed by peers and/or evaluators. The student learning objective results are self-scored on quality and outcome dimensions by teachers annually using a standard scoring rubric. Using the same scoring rubric, evaluators provide an aggregate score every three years of the evaluation cycles based on holistic assessments of the collection of student learning objectives completed by each teacher.
} 
(50 points). The district includes a mix of professional growth activities, service-oriented activities, and teacher leader roles within its point system. A district supervisor, usually the building principal through the evaluation process, approves points teachers submit.

Several districts awarded separate knowledge and skills stipends for national board certification or for district-approved master's and doctoral degrees. In some cases, an annual stipend accompanied reimbursement for completing national board certification, in addition to stipends the state funded. One district reimbursed national board certified teachers with $\$ 2,500$ toward application costs and awarded \$2,500 annual stipends as long as the teachers maintain certification. In this district, national board certified teachers are also eligible for a \$5,000 stipend for teaching in high-poverty schools (those with more than 60 percent of students living in poverty) if they demonstrate proof of receiving an effective or highly effective rating on the Wisconsin Educator Effectiveness System. Another district provides annual \$3,000 stipends for completion national board certification or a district-approved doctorate.

Regardless of the point system approach, other than the national board certification recognition, districts do not appear to require teachers to demonstrate they obtained knowledge and skills. Before points are accepted, they may have had to submit a form for approval in advance of pursuing the opportunity and/or they have to show that they have completed the activity.

Career levels/bands/ladders. To reflect a professional path for educators (as opposed to a uniform step and lane system), about half of the districts in our sample adopted a career level approach, also referred to as career bands or ladders. With this approach, districts use the state licensure categories of initial, professional, and master educator to designate compensationrelated career levels. Others used their own titles or generic descriptions, such as "Level 1, 2, 3, 4" or "Level A-E." The career level model applies knowledge and skills-related activities or accomplishments and, in some cases, performance elements, to determine advancement to different levels. Districts also used a number of steps within each level that allow for incremental pay increases to recognize experience while the teacher remains at the career level. Two examples of career level approaches are presented in Appendices F and G, and described briefly below.

Mosinee (Appendix F) is one district that applied a career level approach, with six "levels" and three "tiers" (steps) within each level (with exception of Level 1, which includes five steps (1A-1E)). Teachers move up each tier/step based on a "successful year of teaching" as determined by principals when they recommend annual contract renewal. Principals use their judgment based on teacher evaluation evidence. Teachers earn a $\$ 650$ stipend in alternate years. Movement to the next level is determined by a "successful year of teaching" and accumulation of professional development points. A teacher needs 18 to move to each subsequent level. The district must approve and offer undergraduate, graduate, or professional development on noncontract days or allow self-directed professional learning (webinars, conferences, etc.). A 
master's degree is required to move from Level 4 to Level 5. Mosinee also created a pay schedule for miscellaneous additional leadership, duty, or coaching positions.

Monona Grove (Appendix G) created a career ladder system with five professional teacher levels: mentorship, post-mentorship, professional, professional teacher-leader, and distinguished. The district aligned the levels with Wisconsin licensure categories. Each level is bounded by a time frame, and includes a basic description, performance expectations, and pay ranges.

Movement between levels is based on a compilation of evidence reviewed by a committee made up of administrators and teacher peers who use a district-developed rubric to determine advancement. All educators receive base pay increases linked to the consumer price index as determined by the district, which is subject to negotiation. Teachers in Levels 3-5 also receive within-level pay increases every 3 years based on a percentage of the salary range mid-point of their current salary level. The amount may fluctuate depending on district finances.

Competitive pay. Almost all of the district representatives interviewed mentioned that they could use incentives to lure or retain employees in high demand positions or who were highly skilled. These incentives were negotiated during the initial contract phase or in continuing contracts. Most districts did not have an overt policy on recruitment and retention incentives nor did they use the incentives as a marketing tool to lure prospective educators. Instead, districts addressed case-by-case situations in which a valued current teacher received an offer from another district or if a high demand position was required. Counter offers tended to be negotiated arrangements between the district administrator and the employee in the form of increased placement on the salary schedule or one-time stipends. No district offered incentives for hard-tostaff schools, though it should be noted that most of the districts either comprised few schools or did not have any identified as hard-to-staff.

To recruit a high quality candidate to a hard-to-fill position, one district offered a school psychologist from another district a substantial raise over what they were earning. The district administrator placed this person at the top of the pay scale, which amounted to a $\$ 10,000$ raise. Some districts offered other incentives, such as assistance toward tuition payment or student loan forgiveness to lure or retain employees in highly competitive fields. Another sought to help teachers gain experience and knowledge for high demand or specialty areas (e.g., educators in science, technology, and math) by offering training opportunities.

Districts wanting to retain teachers sought by other districts also used compensation on a case-by-case basis to keep valued educators. In one instance, to retain a teacher being recruited by another district, a teacher accepted a \$5,000 pay increase that the home district offered.

A couple of districts mentioned examples of more experienced teachers expressing concerns when a newer teacher in a high-demand field was placed higher on the salary schedule than their veteran colleagues. One district stopped pursuing highly desirable candidates to avoid this type of situation. 
In contrast to these ad hoc approaches to competitive pay, one district is more strategic. The district first identifies critical shortage areas as defined by the Wisconsin Department of Public Instruction or national shortage definitions and then examines local data on the number of applications in each teaching field. Teachers in critical shortage areas in this district receive a guaranteed 3-year stipend in a band between $90 \%-110 \%$ of what benchmark districts are paying for those positions. The district then re-evaluates after 3 years to see if the market has adjusted.

Leadership roles. The new systems include leadership roles that are recognized with separate stipends or within point systems. Districts award stipends or points for many varied roles. District documents contained little to no information about the structure, job descriptions, qualifications, or performance assessment for teachers taking on formal leadership roles. Although our interview protocol did not explore these roles and qualifications in depth, Exhibit 9 summarizes our findings as to the types of leadership roles recognized through stipends or accepted within point systems for advancement on salary schedules.

\section{Exhibit 9: Rewards for Formal Teacher Leadership Roles}

\begin{tabular}{|c|c|}
\hline Reward for Teacher Leadership Role & Examples of Teacher Leadership Roles \\
\hline Points & $\begin{array}{l}\text { - } \quad \text { Committee service (district or school) } \\
\text { - } \quad \text { Professional development lead } \\
\text { - } \quad \text { Supervisor of student teachers } \\
\text { - } \quad \text { Community outreach activity coordinator } \\
\text { - District program chair }\end{array}$ \\
\hline Stipend & $\begin{array}{l}\text { - } \text { Teacher mentor } \\
\text { - } \text { Effectiveness coach } \\
\text { - Peer coach for teacher on plan of } \\
\text { improvement } \\
\text { - Department chair }\end{array}$ \\
\hline
\end{tabular}

As reflected in Appendix G, Monona Grove included a "professional leader teacher” designation in its career ladder framework. To meet this designation, teachers must hold and maintain a Wisconsin professional educator or master educator license and demonstrate "clear, convincing, and consistent evidence of advanced standards of classroom teaching practice, collaboration with colleagues, and formal or informal leadership.” Additionally, the district planned to recognize other teacher leader roles that may supplement or replace classroom assignments. These roles could include mentors or teachers on special assignment who are released for a specific time period (i.e., 2-3 years). The district anticipated that they may include other teacher leader roles for classroom teachers (e.g., curriculum coordinators).

Additionally, most districts also retained stipends for extra duty or co-curricular activities, such as coaching a sports team, sponsoring a student club, and working at sporting events or other extracurricular activities. 
Combined plans. Many districts combine multiple features from the above categories; these approaches often utilize career levels. The combined systems clearly moved away from a static steps and lanes model, and included new requirements for annual increases, knowledge and skills components, leadership stipends, and extra duty pay. The School District of Elmbrook's design is described below, and Appendix $\mathrm{H}$ summarizes sections from its plan.

The Elmbrook compensation approach represents a combined plan that is centered on a career level approach, referred to as a career pathway. The plan includes five levels: developing, establishing, mastery 1, mastery 2, and exemplary. Each level includes a different pay range.

The district adjusts teacher base pay using an accumulation of performance evaluation results and other factors assessed every 3 to 5 years by school administrators. Since the state-required evaluation occurs over 3 years and culminates in ratings in the 3rd year, the district developed a "short-cycle" assessment during interim years. The short-cycle form assesses educators on several points related to knowledge, skills, and dispositions. The practice component assesses performance on their student learning objective measure and a district-created measure of professional practice goal completion, which the Wisconsin Educator Effectiveness System requires annually. Based on the annual short-cycle or 3rd-year effectiveness evaluation, teachers may receive an annual $2 \%$ salary increase for proficient performance and $4 \%$ for distinguished performance. This district also created a $\$ 650$ annual bonus for all teachers in schools that received the highest level state school report card rating. A shift in state testing and legislation requiring "a pause" in use of state test results for high stakes decisions prompted the district to suspend this aspect of the program.

In addition, the district includes provisions for teachers in critical shortage areas. The district examines the market for high demand positions (i.e., technology, special education, speech/language, English language learner instructors) and provides stipends to bring employees within $90-110 \%$ of the market rate.

Professional learning is also recognized for teachers taking part in district-approved opportunities that align with school goals and district strategic priorities. A steering committee that includes teachers and administrators develops a menu of opportunities, including approved degrees and certifications. Additional learning opportunities are identified for different career levels, job responsibilities, and improvement focus areas. Completion of the professional learning activities results in a bonus commensurate with the time and value of the learning opportunity to support district goals and objectives. Teacher identified learning opportunities are assigned points by the district based on the time investment and their overall support of the district goals and objectives. The accumulated points correspond to a bonus amount in three levels (Level $1=\$ 250$, Level $2=\$ 500$; Level $3=\$ 800$ ). Teachers identify their learning paths in the fall and submit documentation prior to the start of the next year to receive the appropriate stipends. 
Finally, the district has placed a value on teacher leadership but has not specified how it will compensate teacher leaders. Eventually, promotion opportunities and base pay increases will be tied to mentoring, leadership, and collaboration.

Implementation challenges. Districts expressed a number of challenges about the compensation plan implementation at various stages. These included challenges from teacher associations, difficult meetings during the design phase, concerns about changing relationships between teachers and principals, fragile trust following passage of Act 10, confusion over complexity of plan designs, concerns about availability of professional development opportunities to advance based on professional development units, and tension created when younger teachers were compensated at higher levels than more veteran teachers. The districts appear aware of challenges to their compensation systems. They have tried to address the challenges during the planning steps and continue to monitor the systems for possible revisions.

All districts have processes for teachers to challenge placement in the new systems or decisions related to accumulation of points for salary movement, but thus far the number of challenges were fairly limited. Most districts cited few or no cases.

\section{Summary of Findings}

The following points summarize and highlight key study findings on Wisconsin teacher compensation changes in the 25 sampled districts:

- Small and mid-sized districts throughout the state have designed and implemented new teacher pay systems to modify or replace the single salary schedule since Fall 2011 and passage of Act 10. Although how representative these districts are of other districts across the state is not clear, most in our sample made substantial changes, creating hybrid plans involving several specific reform components.

- The changes were driven by multiple factors, including the new flexibility to transform compensation; a desire to have a pay system that would better attract, reward, and retain teachers; and a need for financial sustainability.

- Pay system changes were mostly designed to meet district needs, rather than simply trying to match or model what other districts were doing. Some districts consulted the Wisconsin Association of School Boards or others for assistance.

- Districts involved teachers, administrators, and teacher association staff (where present) in pay system design and implementation. The involvement aided discussion and the resolution of many challenging issues.

- New pay systems were implemented without a pilot test, but districts were receptive to making changes as the systems unfolded.

- In transition to the new systems, teachers received the same or somewhat greater pay (except in one district).

- In terms of specific pay reforms:

o All sampled districts modified or eliminated traditional steps and lanes.

o About one third of the districts created performance pay tied to teacher evaluations; only one district tied pay to student test score outcomes. 
o Several districts created point systems in which teachers received various amounts of bonus or stipend pay for specific activities, roles, or accomplishments.

o About half of the districts created career ladder/pay band systems, and step increases within each level or band were common.

o Competitive pay was used on an ad hoc basis to attract high quality recruits and/or to fill hard-to-staff positions.

o A few districts began payments to teachers in non-traditional leadership roles, such as teacher mentors.

o Implementation of the new pay systems, and their continuance, were met with several challenges centered around relationship and fairness issues.

\section{Questions for Districts Considering Compensation Changes}

The results of this study raise a number of questions for districts considering changes to their compensation systems or for monitoring their reform strategies. These include:

- Engagement/communication: How are districts engaging teachers in the pay change discussions, testing, and revisions, and when during the process does teacher engagement happen?

- Pay and total compensation satisfaction: Related to above, to what extent are districts monitoring teacher reactions to the compensation changes? Have they considered the total compensation package (direct and indirect pay and benefits) when making changes and gauging reactions?

- How are districts monitoring measurement quality, including the validity and reliability of the measures used for compensation purposes?

- Related to the above, are any of the districts formally or informally evaluating the impact of the changes? Are the new compensation systems having the desired impact on motivation and performance? How are districts measuring the impact of the new systems on teacher, principal, and staff attitudes? How has the community responded to the pay changes?

- Point systems: For those districts using professional development points or credits, who approves them? How often are points disallowed? What is the appeal process?

- Determining sustainability: Are the new pay structures more sustainable than prior compensation approaches? How have districts planned to sustain the new compensation systems? What impact does uncertainty created by schedules that can fluctuate have on employee morale and on retention of top performers or educators in high demand fields (i.e., technology, science, special education, bilingual educators)?

- Administrative complexity: To what extent are these systems adding complexity to district and school administrator roles? Compared to the single-salary structure, these new systems are more complex-someone has to approve all of the professional development units/credits/activities or evaluate performance with pay implications. In some of the systems, principal evaluations of teacher performance affect teacher compensation. To what extent does this system add burden to the principal's role and how does it influence principal decision making (i.e., bias, leniency)? How are districts addressing the added school administrator workload? 


\section{Teacher Compensation in Wisconsin}

- Collegial relationships: Related to the above question, in systems where principal judgments influence compensation, how does this new role affect collegial relationships among school leaders and teachers?

- Transition: How will current employees be transitioned to the new schedule? Should the district add a "sweetener" to ease the transition? What other transition issues/considerations exist?

- Pay equity: How are districts monitoring and addressing concerns or challenges where new teachers may be paid more than experienced teachers through, for example, recruitment incentives?

- Attrition: What effect has the compensation changes had on teacher attraction to the district and retention in general and by subject area?

- What are districts doing in regard to principal pay? Other job categories?

\section{Conclusion}

This study demonstrates widespread district actions to revise teacher compensation systems in Wisconsin. The plans we reviewed varied in several ways. Districts have created systems that fit their local contexts while considering how other districts have proceeded. No one prominent model exists, and it is difficult to categorize the different district approaches into basic model designs (i.e., performance pay or knowledge and skill-based pay), which is a major contrast to the uniform single salary schedule of the past. Elements often exist across district models, with combination plans prominent.

Few districts plan to formally evaluate these changes, though all are taking some steps to periodically monitor the budgetary impact and modifications. Although most of the systems are in place, each district indicated that the adjustments may occur over time based on experience and internal review.

As a final note, we reiterate that this study is illustrative. It may not represent the full range of compensation changes occurring in Wisconsin. If these districts are an indication, however, compensation reforms are clearly another change that may have a dramatic impact in Wisconsin on the profession of teaching and the education system. Additional study on the impact of the new systems on district budgets, attraction and retention of educators, and relationship to other district outcomes merits pursuit. 


\section{Teacher Compensation in Wisconsin}

\section{Further Readings/Resources}

Committee for Economic Development. (2009).Teacher compensation and teacher quality. A statement by the policy and impact committee of the Committee for Economic Development. Available at: https://www.ced.org/pdf/Teacher-Compensation-andTeacher-Quality.pdf

Forbes, B. (2013, August 6). Teacher compensation systems. Session presented at the conference of the Wisconsin Association of School Boards, Milwaukee, WI.

Hanover Research. (2015). Strategic teacher compensation models. Available at: Council of Chief State School Officers, State Consortium on Educator Effectiveness website: http://scee.groupsite.com/file_cabinet/files/777348/download/Strategic\%20Teacher\%20C ompensation\%20Models.pdf?m=1443217586

Hawley Miles, K., Pennington, K., \& Bloom, D. (2015). Do more, add more, earn more:

Teacher salary redesign lessons from 10 first-mover districts. Available at Center for American Progress website: https://cdn.americanprogress.org/wpcontent/uploads/2015/02/TeacherCompensation-report2.pdf

Heneman III, H. G., \& Kimball, S. (2008). How to design new teacher salary structures. Madison: University of Wisconsin, Wisconsin Center for Education Research, Consortium for Policy Research in Education. Strategic Management of Human Capital series. Retrieved from http://www.smhc-cpre.org/download/50/

Heneman III, H. G., Milanowski, A., Kimball, S. M., \& Odden, A. (2006). Standards-based Teacher Evaluation as a Foundation for Knowledge-and Skill-Based Pay (RB-45). Philadelphia, PA: University of Pennsylvania, Graduate School of Education, Consortium for Policy Research in Education. Available at: http://www.cpre.org/sites/default/files/policybrief/885_rb45.pdf

Milanowski, A. T. (2008). Do teacher pay levels matter? A summary. Madison: University of Wisconsin, Wisconsin Center for Education Research, Consortium for Policy Research in Education. Strategic Management of Human Capital series. Available at: http://www.smhccpre.org/download/49/

Odden, A. (2008). How to fund teacher compensation changes. Madison: University of Wisconsin, Wisconsin Center for Education Research, Consortium for Policy Research in Education. Strategic Management of Human Capital series. Available at: http://www.smhccpre.org/download/55/ 
Odden, A. (2008). New teacher pay structures: The compensation side of the strategic management of human capital, a summary. Madison: University of Wisconsin, Wisconsin Center for Education Research, Consortium for Policy Research in Education. Strategic Management of Human Capital series. Retrieved from http://www.smhccpre.org/download/47/

Sielaff, J., \& Zelazoski, S. (2016, January). A primer on teacher compensation models. Presentation at the state convention of the Wisconsin Association of School Boards, Milwaukee, WI.

Pyatigorsky, M., Heneman, H., Steele, C., Finster, M., \& Milanowski, T. Teacher leader programs: Structure and staffing in four TIF districts. Available on request from any of the authors of the working paper. 


\section{References}

Beck, M. (2014, September 7). A teacher 'marketplace' emerges in post-Act 10 Wisconsin. Wisconsin State Journal. Retrieved from http://host.madison.com/wsj/news/local/education/local_schools/a-teacher-marketplaceemerges-in-post-act-wisconsin/article_ab019b52-6ae5-5022-a698-604e5c7bab92.html

Carlson, J. (2006). Alternative teacher compensation in Manitowoc, Wisconsin Six Years Later. Kettle Moraine UniServ Council. Retrieved from Washington State Legislature website: http://leg.wa.gov/JointCommittees/Archive/BEF/Documents/Mtg04-14-08/Carlson3.pdf

Committee for Economic Development. (2009). Teacher compensation and teacher quality. A statement by the policy and impact committee of the Committee for Economic Development. Retrieved from: https://www.ced.org/pdf/Teacher-Compensation-andTeacher-Quality.pdf

Denver Public Schools. (2014). Welcome to teacher ProComp. Retrieved from http://denverprocomp.dpsk12.org/

Firestone, W. A. (1994). Redesigning teacher salary systems for educational reform. American Educational Research Journal, 31(3), 549-574. Retrieved from http://aer.sagepub.com/content/31/3/549.full.pdf

Ford, M. (2012). A modern teacher compensation system for Wisconsin. Wisconsin Policy Research Institute reports, 25(1). Retrieved from http://www.wpri.org/WPRI/Reports/2012/A-Modern-Teacher-Compensation-System-for$\underline{\text { Wisconsin.htm }}$

Hanushek, R. (2007). The single salary schedule and other issues of teacher pay. Peabody Journal of Education, 82(4), 574-586. Retrieved from Stanford University website: http://hanushek.stanford.edu/sites/default/files/publications/hanushek.2007\%20PeabodyJ Ed\%2082(4).pdf

Heneman III, H. G., \& Kimball, S. (2008). How to design new teacher salary structures. Madison: University of Wisconsin, Wisconsin Center for Education Research, Consortium for Policy Research in Education. Strategic Management of Human Capital series. Retrieved from http://www.smhc-cpre.org/download/50/

Mendez, E. (2014, August 18). In the wake of Act 10, school districts changing teacher pay formulas. Milwaukee Journal Sentinel. Retrieved from http://www.jsonline.com/news/education/in-wake-of-act-10-school-districts-changingteacher-pay-formulas-b99321049z1-271617971.html

Odden, A. (2001). Rewarding expertise. Education Next, 1(1). Retrieved from http://educationnext.org/rewarding-expertise/ 
Odden, A., \& Kelley, C. (2002). Paying teachers for what they know and can do: New and smarter compensation strategies to improve student achievement. Thousand Oaks, CA: Corwin Press.

Odden, A., \& Wallace, M. (2008). How to create world class teacher compensation. Freeload Press.

Protsik, J. (1995). History of teacher pay and incentive reforms. Retrieved from http://files.eric.ed.gov/fulltext/ED380894.pdf.

Richards, E. (2012, August 19). School districts explore performance-based pay models: Hartland-Lakeside among Wisconsin districts trying new systems. Milwaukee Journal Sentinel. Retrieved from http://www.jsonline.com/news/education/school-districtsexplore-performancebased-pay-models-186es4a-166708646.html.

Richards, E. (2012, November 22). Waukesha School District considering rewarding teachers for performance. Milwaukee Journal Sentinel. Retrieved from http://www.jsonline.com/news/education/waukesha-school-district-consideringrewarding-teachers-for-performance-fe7Is9r-180541341.html.

Taylor, J. (2015). School committee mulls merit raises, stipends. Northwoods River News. Retrieved from http://www.rivernewsonline.com/main.asp?SectionID=6\&SubSection.

TNTP. (2014). Shortchanged: The hidden costs of lockstep teacher pay. Retrieved from http://tntp.org/assets/documents/TNTP_Shortchanged_2014.pdf.

Uhlig, K. (2014, July 26). Wausau schools hike teacher pay under new salary model. Wausau Daily Herald. Retrieved from http://www.wausaudailyherald.com/story/news/local/2014/07/26/teacher-salariesrising/13209803/.

U.S. Department of Education. (2016, July 18). Teacher incentive fund [Web page]. Retrieved from http://www2.ed.gov/programs/teacherincentive/index.html

U.S. Department of Education. (2016, June 6). Race to the top [Web page]. Retrieved from http://www2.ed.gov/programs/racetothetop/index.html

Wisconsin Act 10. (2011). Retrieved from Wisconsin Legislature website: https://docs.legis.wisconsin.gov/2011/related/acts/10.pdf 


\section{Appendix A: Participating Districts}

\begin{tabular}{|l|c|}
\hline District & $\begin{array}{c}\text { Student } \\
\text { Enrollment } \\
\text { (2015-16) }\end{array}$ \\
\hline Adams-Friendship & 1,567 \\
\hline Athens & 414 \\
\hline Beloit-Turner & 1,528 \\
\hline DeForest & 3,636 \\
\hline Elmbrook & 7,055 \\
\hline Fall Creek & 839 \\
\hline Goodman-Armstrong Creek & 105 \\
\hline Grafton & 2,214 \\
\hline Greenfield & 3,638 \\
\hline Kiel & 1,300 \\
\hline Menomonie Area & 4,049 \\
\hline Middleton-Cross Plains & 7,006 \\
\hline Monona Grove & 3,333 \\
\hline Mosinee & 2,080 \\
\hline Neenah & 6,570 \\
\hline Northland Pines & 1,311 \\
\hline Oak Creek-Franklin & 6,617 \\
\hline Oshkosh & 9,913 \\
\hline Ripon & 1,639 \\
\hline Sheboygan Area & 10,405 \\
\hline Stanley-Boyd & 1,080 \\
\hline Sun Prairie & 8,118 \\
\hline Verona & 5,420 \\
\hline Wausaukee & 468 \\
\hline Wauwatosa & 7,262 \\
\hline & \\
\hline & \\
\hline
\end{tabular}




\section{Appendix B: Telephone Interview Protocol for School District Leaders about Teacher Compensation}

1. Prior to your new compensation system, did your district use the single salary schedule for teachers?

a. [if yes] How many steps and lanes did it have?

b. [if no] What system was used?

2. In your new system, did you make modifications to the single salary schedule or eliminate it? [if modified] What general modifications were made? (e.g., reducing the number of steps or lanes, creating salary tiers or career bands)

3. Under the new compensation system, on what basis will teachers receive salary increases that are built into their base pay?
a. teacher evaluation ratings?
b. student test scores?
c. completion of specific activities: (professional development, formal educational credits, participation in special events or programs)
d. experience/seniority?
e. New instructional leadership roles or responsibilities, such as master or mentor teacher
f. any other? (please describe)

4. Are teachers eligible for bonus pay (i.e., compensation not built into base pay)?
a. [if yes, what actions or accomplishments can lead to a bonus?]

5. How is starting salary determined for teachers new to teaching?

6. How is starting salary determined for teachers new to the district?

7. Does your district offer incentives to recruit and retain teachers in certain positions?
a. [if yes, please describe].

8. Does your district offer incentives to recruit and retain teachers in hard-to-staff schools?
a. [if yes, please describe]

9. Is participation in these new compensation systems required of all teachers?

a. [If no, which teachers are exempt?]

10. How are you funding the new compensation system? (using the same amount in compensation budget, but using it differently; getting additional revenue) 


\section{Moving to the New Compensation System}

11. What factors led the district to change its compensation system for teachers?

12. How are the changes related to district goals or priorities?

13. Who was involved in the design of the changes and how long did the design phase take?

14. What were the key barriers to the design process and how did you work through those?

15. What other factors helped with the design process?

16. Did you model any other district's system? (if so, which one(s)?)

17. Did you utilize the Wisconsin Association of School Boards or other professional associations?

\section{Current Implementation of the New System}

18. Was there a pilot of the new system?

a. [If yes], who was involved?

19. How far along is the district in implementation? (e.g., 100\%, $80 \%$ etc.)

20. How well has the implementation process proceeded?

a. Have there been any stumbling blocks to implementation?

b. What about positive attributes helping with implementation?

21. One last question: Is it possible for us to receive a copy of a description of your new compensation system?

[If yes, offer to send an email reminder to the participant so that he/she can send you the document.]

[If no, “OK, well you’ve already given us plenty of helpful information today.”]

22. Those are all the questions I have for you today, but is there anything else you would like to add? 


\section{Appendix C: Northland Pines School District 2015-16 All Classroom Instructors Salary Schedule}

\begin{tabular}{|c|c|c|c|c|}
\hline $\begin{array}{l}\text { Standards and } \\
\text { Benchmarks }\end{array}$ & $\begin{array}{l}\text { I } \\
\text { Developing } \\
\$ 40,000\end{array}$ & $\begin{array}{l}\text { II } \\
\text { Proficient } \\
\$ 47,564\end{array}$ & $\begin{array}{l}\text { III } \\
\text { Highly Effective } \\
\$ 55,093\end{array}$ & $\begin{array}{l}\text { IV } \\
\text { Distinguished } \\
\$ 65,263\end{array}$ \\
\hline \multicolumn{5}{|c|}{ Professional } \\
\hline $\begin{array}{l}\text { Understanding } \\
\text { of Subject } \\
\text { Content }\end{array}$ & \begin{tabular}{|l|} 
Lessons demonstrate \\
deep understanding of \\
differentiated learning
\end{tabular} & $\begin{array}{l}\text { Lessons demonstrate } \\
\text { deep understanding of } \\
\text { differentiated learning } \\
\text { above and below grade } \\
\text { level }\end{array}$ & $\begin{array}{l}\text { Demonstrates extensive } \\
\text { understanding of subject } \\
\text { matter and guides others } \\
\text { within grade level/ } \\
\text { department and building }\end{array}$ & $\begin{array}{l}\text { Demonstrates extensive } \\
\text { understanding of subject matter } \\
\text { and consistently provides } \\
\text { leadership within the district }\end{array}$ \\
\hline $\begin{array}{l}\text { Understanding } \\
\text { of Student } \\
\text { Growth and } \\
\text { Development }\end{array}$ & $\begin{array}{l}\text { Demonstrates under- } \\
\text { standing of the social, } \\
\text { emotional, intellectual, } \\
\text { and physical devel- } \\
\text { opment of students }\end{array}$ & $\begin{array}{l}\text { Successfully } \\
\text { accommodates the } \\
\text { unique needs and } \\
\text { interests of students }\end{array}$ & $\begin{array}{l}\text { Enhances the individual } \\
\text { learning experience through } \\
\text { differentiation }\end{array}$ & $\begin{array}{l}\text { Consistently promotes } \\
\text { academic gains through } \\
\text { differentiated instruction while } \\
\text { enhancing individual learning } \\
\text { experience as evidenced by } \\
\text { student products }\end{array}$ \\
\hline Curriculum & \begin{tabular}{|l|} 
Implements the \\
adopted district \\
curriculum/standards \\
to fidelity
\end{tabular} & $\begin{array}{l}\text { Improves the adopted } \\
\text { district curriculum through } \\
\text { collaboration }\end{array}$ & $\begin{array}{l}\text { Assumes teacher-leader } \\
\text { responsibilities in area of } \\
\text { curriculum and shares } \\
\text { expertise within the district }\end{array}$ & $\begin{array}{l}\text { Assumes teacher-leader } \\
\text { responsibilities in area of } \\
\text { curriculum and shares expertise } \\
\text { within the district, region, and } \\
\text { educational field }\end{array}$ \\
\hline \multicolumn{5}{|c|}{ Instructional Planning } \\
\hline $\begin{array}{l}\text { District } \\
\text { Standards }\end{array}$ & \begin{tabular}{|l|} 
Implements stan- \\
dards-based instruc- \\
tion using various \\
strategies to enhance \\
student growth
\end{tabular} & $\begin{array}{l}\text { Evaluates the effective- } \\
\text { ness of standards-based } \\
\text { instruction as measured } \\
\text { by student growth }\end{array}$ & $\begin{array}{l}\text { Revises instruction as } \\
\text { needed based on student } \\
\text { growth regarding district } \\
\text { standards }\end{array}$ & $\begin{array}{l}\text { Collaboratively revises } \\
\text { instruction as needed based on } \\
\text { district standards, updating } \\
\text { when necessary in relation to } \\
\text { district-approved standards }\end{array}$ \\
\hline $\begin{array}{l}\text { Data and } \\
\text { Research }\end{array}$ & $\begin{array}{l}\text { Uses data to drive } \\
\text { instruction }\end{array}$ & $\begin{array}{l}\text { Collaborates with } \\
\text { colleagues to review and } \\
\text { adjust instruction based } \\
\text { on data }\end{array}$ & \begin{tabular}{|l|} 
Collects data and uses \\
findings to make data-driven \\
decisions for instruction in \\
the classroom and school \\
\end{tabular} & $\begin{array}{l}\text { Collects data and uses findings } \\
\text { to make data-driven decisions } \\
\text { for instruction in the classroom, } \\
\text { school and district }\end{array}$ \\
\hline $\begin{array}{l}\text { Interdisciplinary } \\
\text { Learning } \\
\text { Experiences }\end{array}$ & \begin{tabular}{|l|} 
Collaborates with \\
colleagues to develop \\
lessons containing \\
more than one \\
content area or \\
standard
\end{tabular} & $\begin{array}{l}\text { Collaborates with grade- } \\
\text { level team or depart- } \\
\text { ments within own building } \\
\text { community to develop } \\
\text { interdisciplinary lessons } \\
\text { containing more than one } \\
\text { content area or standard }\end{array}$ & $\begin{array}{l}\text { Collaborates with colleagues } \\
\text { to consistently expand } \\
\text { interdisciplinary learning to } \\
\text { participants beyond the } \\
\text { classroom and applied to } \\
\text { real world applications }\end{array}$ & $\begin{array}{l}\text { Collaborates with community } \\
\text { members in planning lessons } \\
\text { and consistently provides } \\
\text { interdisciplinary experiences } \\
\text { that apply to real world } \\
\text { applications }\end{array}$ \\
\hline \multicolumn{5}{|c|}{ (3) Instructional Delivery } \\
\hline Technology & $\begin{array}{l}\text { Infuses technology } \\
\text { into instruction }\end{array}$ & \begin{tabular}{|l|} 
Strategically uses a \\
variety of technologies to \\
meet student needs
\end{tabular} & $\begin{array}{l}\text { Classroom technology } \\
\text { redefines the learning } \\
\text { experience to increase } \\
\text { student outcomes }\end{array}$ & $\begin{array}{l}\text { Impacts students and col- } \\
\text { leagues beyond own classroom } \\
\text { in the use of technology to } \\
\text { increase student outcomes }\end{array}$ \\
\hline $\begin{array}{l}\text { Differentiated } \\
\text { Instruction }\end{array}$ & $\begin{array}{l}\text { Understands and } \\
\text { implements } \\
\text { differentiated } \\
\text { instruction }\end{array}$ & $\begin{array}{l}\text { Implements differentiated } \\
\text { instruction based on } \\
\text { formal and informal data }\end{array}$ & \begin{tabular}{|l|} 
Differentiates instruction \\
based on multiple \\
intelligences to meet the \\
diverse needs and interests \\
of students
\end{tabular} & $\begin{array}{l}\text { Classroom structure models } \\
\text { differentiation by continually } \\
\text { adjusting instruction based on } \\
\text { ongoing assessment }\end{array}$ \\
\hline Questioning & $\begin{array}{l}\text { Uses questioning to } \\
\text { improve student } \\
\text { outcomes }\end{array}$ & $\begin{array}{l}\text { Uses a wide variety of } \\
\text { questioning techniques to } \\
\text { engage learners }\end{array}$ & $\begin{array}{l}\text { Questions at various cog- } \\
\text { nitive levels and provides } \\
\text { opportunities for feedback } \\
\text { from and between students }\end{array}$ & $\begin{array}{l}\text { Students regularly demonstrate } \\
\text { higher level questioning and } \\
\text { thinking }\end{array}$ \\
\hline
\end{tabular}


Teacher Compensation in Wisconsin

\begin{tabular}{|c|c|c|c|c|}
\hline \multicolumn{5}{|c|}{ (4) Assessment } \\
\hline $\begin{array}{l}\text { Summative I } \\
\text { Formative I } \\
\text { Common }\end{array}$ & $\begin{array}{l}\text { Develops and uses } \\
\text { multiple forms of } \\
\text { assessments }\end{array}$ & $\begin{array}{l}\text { Instruction is based on } \\
\text { pre/post assessment } \\
\text { results and methods }\end{array}$ & \begin{tabular}{|l} 
Analyzes data to write, \\
revise and maintain \\
the grade level or \\
department assessments
\end{tabular} & $\begin{array}{l}\text { Analyzes data to write, revise } \\
\text { and implement the grade-level } \\
\text { or department assessments to } \\
\text { help with districtwide curriculum } \\
\text { decisions }\end{array}$ \\
\hline $\begin{array}{l}\text { Student } \\
\text { Feedback }\end{array}$ & $\begin{array}{l}\text { Provides opportunity } \\
\text { for student feedback }\end{array}$ & $\begin{array}{l}\text { Creates and implements } \\
\text { diverse methods to } \\
\text { acquire student feedback }\end{array}$ & $\begin{array}{l}\text { Individual student feedback } \\
\text { impacts teacher practice }\end{array}$ & $\begin{array}{l}\text { Collaborating with students to } \\
\text { develop independent learning }\end{array}$ \\
\hline \multicolumn{5}{|c|}{ Learning Environment } \\
\hline Physical & \begin{tabular}{|l|} 
Classroom provides a \\
safe environment
\end{tabular} & $\begin{array}{l}\text { Classroom stimulates } \\
\text { learning and establishes } \\
\text { routines }\end{array}$ & \begin{tabular}{|l|} 
Physical environment of \\
classroom is thoughtfully \\
arranged, reflecting teaching \\
and learning characteristics \\
of class
\end{tabular} & $\begin{array}{l}\text { Classroom physical } \\
\text { environment is dynamic and } \\
\text { changes to suit purposes of } \\
\text { instruction }\end{array}$ \\
\hline $\begin{array}{l}\text { Classroom } \\
\text { Culture }\end{array}$ & $\begin{array}{l}\text { Acknowledges } \\
\text { Students' interests } \\
\text { and abilities in and out } \\
\text { of school }\end{array}$ & $\begin{array}{l}\text { Incorporates students' } \\
\text { interests and abilities in } \\
\text { and out of school and } \\
\text { inclusive learning } \\
\text { environment }\end{array}$ & \begin{tabular}{|l|} 
Students are openly \\
engaged and participating in \\
a variety of classroom roles \\
and activities within a \\
trusting and respectful \\
environment
\end{tabular} & $\begin{array}{l}\text { Students and teachers } \\
\text { cooperatively participate in } \\
\text { creating a safe environment for } \\
\text { risk-taking opportunities }\end{array}$ \\
\hline $\begin{array}{l}\text { Classroom } \\
\text { Management }\end{array}$ & $\begin{array}{l}\text { Expectations are } \\
\text { posted, taught, } \\
\text { modeled and } \\
\text { practiced }\end{array}$ & $\begin{array}{l}\text { Expectations are consis- } \\
\text { tently modeled and de- } \\
\text { monstrated by the stu- } \\
\text { dents in a variety of } \\
\text { settings } \\
\end{array}$ & $\begin{array}{l}\text { Students understand } \\
\text { expectations and are self- } \\
\text { managed }\end{array}$ & $\begin{array}{l}\text { Students understand } \\
\text { expectations and are } \\
\text { consistently self- managed }\end{array}$ \\
\hline $\begin{array}{l}\text { Student } \\
\text { Engagement }\end{array}$ & $\begin{array}{l}\text { Teacher directs } \\
\text { learning for students } \\
\text { engagement }\end{array}$ & $\begin{array}{l}\text { Teachers uses a variety } \\
\text { of instructional strategies } \\
\text { to increase student } \\
\text { engagement }\end{array}$ & $\begin{array}{l}\text { Teacher facilitation } \\
\text { promotes self-directed } \\
\text { learning }\end{array}$ & $\begin{array}{l}\text { Teacher consistently facilitates } \\
\text { student learning and provides } \\
\text { authentic learning experiences }\end{array}$ \\
\hline \multicolumn{5}{|c|}{ (6) $\quad$ Professionalism } \\
\hline $\begin{array}{l}\text { Professional } \\
\text { Development }\end{array}$ & $\begin{array}{l}\text { Participates in } \\
\text { professional } \\
\text { development } \\
\text { opportunities }\end{array}$ & $\begin{array}{l}\text { Applies acquired } \\
\text { practices in classroom }\end{array}$ & \begin{tabular}{|l|} 
Consistently collaborates \\
with colleagues on acquired \\
knowledge
\end{tabular} & $\begin{array}{l}\text { Impacts students and col- } \\
\text { leagues beyond own classroom } \\
\text { in the use of best practice to } \\
\text { increase student outcomes }\end{array}$ \\
\hline $\begin{array}{l}\text { Building } \\
\text { Positive } \\
\text { Relationships }\end{array}$ & \begin{tabular}{|l|} 
Builds positive \\
relationships with \\
students, families, and \\
colleagues
\end{tabular} & $\begin{array}{l}\text { Builds positive } \\
\text { relationships across the } \\
\text { district }\end{array}$ & $\begin{array}{l}\text { Builds positive relations } \\
\text { within the community }\end{array}$ & $\begin{array}{l}\text { Builds positive partnerships with } \\
\text { community that result in } \\
\text { authentic learning opportunities }\end{array}$ \\
\hline $\begin{array}{l}\text { Professional } \\
\text { Responsibility }\end{array}$ & $\begin{array}{l}\text { Adheres to school } \\
\text { district, legal, ethical } \\
\text { and procedural } \\
\text { requirements }\end{array}$ & $\begin{array}{l}\text { Accepts additional } \\
\text { responsibilities when } \\
\text { asked }\end{array}$ & \begin{tabular}{|l|} 
Independently pursues \\
additional responsibilities, \\
duties, roles, tasks
\end{tabular} & $\begin{array}{l}\text { Independently pursues } \\
\text { additional responsibilities } \\
\text { outside of school hours }\end{array}$ \\
\hline $\begin{array}{l}\text { Ability to Self- } \\
\text { Reflect }\end{array}$ & $\begin{array}{l}\text { Uses EE as a self- } \\
\text { reflection tool to } \\
\text { improve practice }\end{array}$ & $\begin{array}{l}\text { Positive change occurs } \\
\text { based on reflections }\end{array}$ & $\begin{array}{l}\text { Shares reflections and } \\
\text { seeks feedback from } \\
\text { colleagues }\end{array}$ & $\begin{array}{l}\text { Ongoing self-reflection } \\
\text { enhances student outcomes }\end{array}$ \\
\hline \begin{tabular}{l|} 
Parent/ \\
Guardian \\
Communication
\end{tabular} & \begin{tabular}{l|} 
Creates and \\
contributes to building \\
and/or classroom \\
communication tools
\end{tabular} & $\begin{array}{l}\text { Utilizes multiple formats } \\
\text { to enhance personal } \\
\text { communication }\end{array}$ & $\begin{array}{l}\text { Facilitates appropriate two- } \\
\text { way communication based } \\
\text { on family needs }\end{array}$ & $\begin{array}{l}\text { Effectively utilizes feedback } \\
\text { from all stakeholders to } \\
\text { increase student outcomes }\end{array}$ \\
\hline
\end{tabular}




\section{Appendix D: Neenah Joint School District 2014-15 Staff Salary Schedule}

\begin{tabular}{|c|c|c|c|c|}
\hline $\begin{array}{l}\text { PERFORMANCE } \\
\text { LEVEL }\end{array}$ & \multicolumn{3}{|l|}{ INDICATORS } & $\begin{array}{l}\text { COMPENSATION } \\
\text { RANGE* }^{*}\end{array}$ \\
\hline Exemplary & \multicolumn{3}{|c|}{$\begin{array}{l}\text { - Has met the highest level at Quality } 5 \\
\text { - Distinguished in all standards } \\
\text { - Regularly contributes to innovative improvements that benefit the entire } \\
\text { District } \\
\text { - Continues to elicit new ideas and initiatives that benefit and enrich the entire } \\
\text { District. } \\
\text { - Contributes to recognized District-wide enhancements that align with the } \\
\text { District mission, vision and strategic areas of focus } \\
\text { - Provides innovative ideas that have led to District-wide change } \\
\text { - Is highly respected at the building and District levels }\end{array}$} & $\$ 69,352$ - $\$ 77,452$ \\
\hline \multirow[t]{2}{*}{ Quality 5} & 5.3 & 5.2 & 5.1 & \multirow[t]{2}{*}{$\$ 61,708-\$ 72,352$} \\
\hline & $\begin{array}{l}\text { - } \text { Has fulfilled all criteria in } \\
5.2 \\
\text { - Leads building level } \\
\text { teams } \\
\text { - } \text { Contributes to recognized } \\
\text { improvements at the } \\
\text { District level } \\
\text { - Exhibits instructional } \\
\text { - leadership school-wide } \\
\text { that evidences } \\
\text { documented gains in } \\
\text { student learning } \\
\text { - Distinguished in all areas } \\
\text { or at least five standards } \\
\text { and effective in the other }\end{array}$ & $\begin{array}{l}\text { - Has fulfilled criteria in } \\
5.1 \\
\text { - Provides assistance } \\
\text { and expertise to } \\
\text { colleagues to gain } \\
\text { knowledge and skills in } \\
\text { pedagogy or use of } \\
\text { resources } \\
\text { - Documented evidence } \\
\text { of student gains is } \\
\text { recognized in a } \\
\text { consistent manner }\end{array}$ & $\begin{array}{l}\text { - Has met the } \\
\text { highest criteria at } \\
\text { Quality } 4 \\
\text { - Distinguished in at } \\
\text { least four } \\
\text { standards and at } \\
\text { least effective in } \\
\text { the others }\end{array}$ & \\
\hline \multirow[t]{2}{*}{ Quality 4} & 4.3 & 4.2 & 4.1 & \multirow[t]{2}{*}{$\$ 55,000-\$ 65,708$} \\
\hline & $\begin{array}{l}\text { - Has fulfilled all criteria in } \\
4.2 \\
\text { - Provides leadership for } \\
\text { school improvement } \\
\text { - Demonstrates advanced } \\
\text { knowledge and } \\
\text { application of best } \\
\text { practices pertaining to } \\
\text { instruction and } \\
\text { assessment } \\
\text { - Distinguished in at least } \\
\text { three standards and at } \\
\text { least effective in the } \\
\text { others } \\
\text { - Takes initiative to find } \\
\text { solutions to potential gaps } \\
\text { and challenges at the } \\
\text { building and/or District } \\
\text { level }\end{array}$ & $\begin{array}{l}\text { - Has fulfilled criteria in } \\
4.1 \\
\text { - Applies high level } \\
\text { inquiry-based learning }\end{array}$ & $\begin{array}{l}\text { - Has met the } \\
\text { highest level at } \\
\text { Quality } 3 \\
\text { - Distinguished in at } \\
\text { least two } \\
\text { standards and at } \\
\text { least effective in } \\
\text { the others } \\
\text { - Analyzes and } \\
\text { interprets student } \\
\text { data that includes } \\
\text { District } \\
\text { improvement } \\
\text { trends and } \\
\text { provides } \\
\text { documented } \\
\text { evidence of } \\
\text { student } \\
\text { performance gains }\end{array}$ & \\
\hline
\end{tabular}


Teacher Compensation in Wisconsin

\begin{tabular}{|c|c|c|c|c|}
\hline \multirow[t]{2}{*}{ Quality 3} & - 3.3 & - 3.2 & - 3.1 & \multirow[t]{2}{*}{$\$ 47,000-\$ 59,735$} \\
\hline & $\begin{array}{l}\text { - Has fulfilled all criteria in } \\
3.2 \\
\text { - Understands and exhibits } \\
\text { the use of best } \\
\text { instructional practices } \\
\text { - Exhibits and encourages } \\
\text { collaboration } \\
\text { - Distinguished in at least } \\
\text { one standard and at least } \\
\text { effective in the others }\end{array}$ & $\begin{array}{l}\text { - Has fulfilled criteria in } \\
3.1 \\
\text { - Implements The } \\
\text { District curriculum, } \\
\text { instruction, and } \\
\text { assessment with } \\
\text { fidelity (e.g. balanced } \\
\text { literacy) }\end{array}$ & \begin{tabular}{|l} 
- \\
has met the \\
highest level at \\
Quality 2 \\
- At least Effective in \\
all areas of \\
performance \\
standards \\
- Applies use of \\
resources and \\
demonstrates \\
knowledge in \\
content areas \\
- Provides evidence \\
of documented \\
student growth and \\
proficiency
\end{tabular} & \\
\hline \multirow[t]{2}{*}{ Quality 2} & 2.3 & 2.2 & 2.1 & \multirow[t]{2}{*}{$\$ 43,880-\$ 49,980$} \\
\hline & $\begin{array}{l}\text { - Has fulfilled criteria in } 2.2 \\
\text { - Presents and contributes } \\
\text { a positive and } \\
\text { professional approach in } \\
\text { problem solving and } \\
\text { responses to school or } \\
\text { District initiatives and } \\
\text { challenges }\end{array}$ & $\begin{array}{l}\text { - Has fulfilled the criteria } \\
\text { in } 2.1 \\
\text { - Establishes and has } \\
\text { documented evidence } \\
\text { of strong positive } \\
\text { relationships with } \\
\text { students, parents, and } \\
\text { colleagues }\end{array}$ & \begin{tabular}{|l} 
- \\
has met the \\
Quahest level at \\
Quality 1 \\
- Effective in at least \\
five areas of \\
performance and \\
developing/ needs \\
improvement in not \\
more than one \\
area of standards
\end{tabular} & \\
\hline \multirow[t]{2}{*}{ Quality 1} & 1.3 & 1.2 & 1.1 & \multirow[t]{2}{*}{$\$ 41,000-\$ 44,880$} \\
\hline & $\begin{array}{l}\text { - Has fulfilled the criteria in } \\
\text { the } 1.2 \text { category } \\
\text { - Effective in at least four } \\
\text { standard areas } \\
\text { - Evaluates student } \\
\text { learning that guides } \\
\text { instructional practice } \\
\text { - Maximizes the use of } \\
\text { class time }\end{array}$ & $\begin{array}{l}\text { - Meets expectations } \\
\text { related to deadlines or } \\
\text { other areas defined by } \\
\text { the principal and/or } \\
\text { District } \\
\text { - Provides } \\
\text { developmentally } \\
\text { appropriate } \\
\text { interventions and } \\
\text { accommodations for } \\
\text { students. }\end{array}$ & $\begin{array}{l}\text { - Demonstrates } \\
\text { ability to meet } \\
\text { minimal } \\
\text { expectations } \\
\text { aligned with } \\
\text { his/her position } \\
\text { - Performance is } \\
\text { inconsistent and } \\
\text { improvement will } \\
\text { be necessary }\end{array}$ & \\
\hline $\begin{array}{l}\text { Plan of } \\
\text { Assistance }\end{array}$ & \multicolumn{4}{|c|}{$\begin{array}{l}\text { Employees may be placed on a Plan of Assistance at any time throughout the school year if there are } \\
\text { concerns by the administration. During this period, the employee will be expected to fulfill all } \\
\text { components as prescribed by the Plan. }\end{array}$} \\
\hline \multicolumn{5}{|c|}{$\begin{array}{l}\text { *Compensation ranges may adjust annually based upon negotiated base wages and/or Board of Education decisions. } \\
\text { Note: Before advancing to the next "cell," all areas must be met in the next cell. For example, prior to moving from } 3.3 \text {, all } \\
\text { indicators in } 3.3 \text { and before must be fulfilled. This process is how we approach determining the EP performance of } \\
\text { distinguished, effective, etc. }\end{array}$} \\
\hline
\end{tabular}


Teacher Compensation in Wisconsin

\section{Appendix E: School District of the Menominee Area Professional Performance Point Examples}

\begin{tabular}{|c|c|c|}
\hline & Points & Examples/Contact Person \\
\hline $\begin{array}{l}\text { Workshop and Implementation Report w/prior approval } \\
\text { Approved form required }\end{array}$ & 5 pts/per event/day & $\begin{array}{l}\text { CESA workshops, SLATE, UW sponsored training, DPI workshops, } \\
\text { resiliency training, district after-hours workshops } \\
\text { Contact Supervisor and/or Director }\end{array}$ \\
\hline Community Education Course Instructor (non-paid) & 5 pts per session & Contact Community Ed Coordinator \\
\hline Volunteer at district sponsored event & 5 pts per event & PTO Event, game worker, supervision, chaperone, family night event \\
\hline $\begin{array}{l}\text { Instructional Study Team w/prior approval } \\
\text { Approved form required }\end{array}$ & $10 \mathrm{pts}$ & $\begin{array}{l}\text { Integrating technology, researching or studying a new idea for possible } \\
\text { implementation. }\end{array}$ \\
\hline $\begin{array}{l}\text { Graduate Course w/prior approval } \\
\text { Approved form required }\end{array}$ & 10 pts/credit hour & Contact HR \\
\hline Grant Writing/Facilitation (requires prior approval) & $10 \mathrm{pts}<\$ 5,000$ & Contact Supervisor and Business Office \\
\hline PDP Reviewer (must be actively serving on a team) & $10 \mathrm{pts}$ & Self-Application \\
\hline Peer Coaching & $10 \mathrm{pts} /$ per teacher & Contact Supervisor and Dir. Of Instr. \\
\hline $\begin{array}{l}\text { Workshop/PD Presenter (choice of pay or points) } \\
\text { Approved form required }\end{array}$ & $10 \mathrm{pts} /$ per session & Contact Supervisor and Dir. Of Instr. \\
\hline District Sponsored Athletic Youth Clinic & $10 \mathrm{pts} /$ per session & Summer, evening, or weekend clinic for sports \\
\hline Community Outreach Activity - Coordinator & $10 \mathrm{pts} /$ per session & $\begin{array}{l}\text { Group Service learning projects, group community service projects, } \\
\text { Homecoming parade, coordinating family events, participating on a } \\
\text { community board as a school district rep. for specific projects with a need to } \\
\text { coordinate with district programming }\end{array}$ \\
\hline Supervising student teacher (limit: 2 per year) w/approval & 10 pts/per qtr. & Contact HR \\
\hline $\begin{array}{l}\text { Obtaining and maintaining specialized certification(s) or training - } \\
\text { w/prior approval }\end{array}$ & $\begin{array}{l}25 \text { pts/per } \\
\text { certification }\end{array}$ & Provide proof of certification to HR (i.e. PLTW, AP, EMT, National Board) \\
\hline Grant Writing/Facilitation & $25 \mathrm{pts}>\$ 5,000$ & Contact Supervisor and Business Office \\
\hline Mentor & $25 \mathrm{pts}$ & Contact HR \\
\hline Publishing in professional journal & $25 \mathrm{pts}$ & Provide copy of article to Supervisor \\
\hline Presenting at Conferences/Conventions w/approval & $25 \mathrm{pts}$ & Professional Conferences, CESA Events \\
\hline $\begin{array}{l}\text { Action Research Project/Team w/ prior district approval } \\
\text { Approved form required }\end{array}$ & $25 \mathrm{pts}$ & Implementation and study of a new or revised instructional practice \\
\hline
\end{tabular}


Teacher Compensation in Wisconsin

\begin{tabular}{|c|c|c|}
\hline Innovative Curriculum Project w/prior district approval & $25 \mathrm{pts}$ & $\begin{array}{l}\text { Integrated subject matter project, Implementing a special topics course, } \\
\text { Innovative project-based learning, Integrated technology project, Reality } \\
\text { Zone, Poverty Simulation, School-Wide Project, Special Projects with UW } \\
\text { System }\end{array}$ \\
\hline Building Leadership Team & $25 \mathrm{pts}$ & $\begin{array}{l}\text { Site team, building leadership teams, PBIS team, governance team, data } \\
\text { retreat team, parent advisory boards, PTO board, Site wellness committee, } \\
\text { Gifted and talented program site coordinators }\end{array}$ \\
\hline District Leadership Team & $25 \mathrm{pts}$ & $\begin{array}{l}\text { Instructional Leadership Team, district technology team, Quality } \\
\text { Improvement Team, Wellness Committee, Strategic Plan Action Team, } \\
\text { New resource study team, Pupil Services Team, Building Assessment SAC }\end{array}$ \\
\hline Department, Grade Level, Project Chair & $25 \mathrm{pts}$ & Contact Dir. Of Instruction \\
\hline Professional Association State-wide Officer Position & $25 \mathrm{pts}$ & Contact Supervisor \\
\hline Adviser to Student with State-wide Officer Position & $25 \mathrm{pts}$ & Contact Supervisor \\
\hline District Special Project Participant - prior district approval & $25 \mathrm{pts}$ & $\begin{array}{l}\text { Dept. or grade level curriculum project, strategic plan project, assessment } \\
\text { project, technology integration project }\end{array}$ \\
\hline $\begin{array}{l}\text { Book/Literature Study Group - prior district approval } \\
\text { Approved form required }\end{array}$ & $25 \mathrm{pts}$ & Book Studies, Literature and/or resource review with specific topic \\
\hline International Travel with Students - Board Approval Required & $25 \mathrm{pts} /$ per trip & Contact HS Principal \\
\hline $\begin{array}{l}\text { Intensive Tutoring or Mentoring to reach approved Ind. Student } \\
\text { Learning Objective(SLO)/extension of student day (Requires prior } \\
\text { approval) }\end{array}$ & 25 pts/per plan & Before and after school study sessions, Big Brother/Little Sister program, \\
\hline $\begin{array}{l}\text { Enrichment Activity to reach approved individual Student Learning } \\
\text { Objective (SLO)/extension of student day (requires prior approval) }\end{array}$ & 25 pts/per plan & Non-pointed co/extra-curricular clubs, Special student projects \\
\hline District Program Coordinator & $50 \mathrm{pts}$ & $\begin{array}{l}\text { Reading Specialist, Chemical Hygiene, Library Media, Wellness, Health } \\
\text { Coordinator, Webmaster for department or building }\end{array}$ \\
\hline District Trainer & $50 \mathrm{pts}$ & $\begin{array}{l}\text { Technology Trainers, Literacy Coach, Assessment Trainers, External and } \\
\text { Internal PBIS Coaches, Health Realization, Curriculum Trainer, Health } \\
\text { Related Training }\end{array}$ \\
\hline $\begin{array}{l}\text { Exchange } 2 \text { pts. of a Co-curricular or Extra-curricular Activity (limit } 2 \\
\text { per year) }\end{array}$ & $50 \mathrm{pts}$ & Contact Supervisor and HR \\
\hline Coaching two or more MS/HS extracurricular or co-curricular activities & $50 \mathrm{pts}$ & Contact Supervisor and HR \\
\hline SPECIAL REQUEST (i.e. Fulbright Teacher Exchange) & $\begin{array}{l}\text { To be determined } \\
\text { by HR }\end{array}$ & Contact Supervisor and HR \\
\hline
\end{tabular}




\section{Appendix F: Mosinee School District Compensation Schedule for Professional Educators}

The Mosinee Compensation Schedule will be implemented as presented here. A quarterly review of the compensation schedule will be conducted each year with a final review occurring prior to April 1 of each year. At the end of the annual review recommendations for changes, additions or deletions to the Compensation Schedule will be brought to the Board of Education for their consideration.

Professional Educators must be in good standing, as defined by satisfactory performance and will not be on a plan of improvement in order to enter into and continue to progress through the compensation schedule or to receive a stipend.

Professional Educators will move vertically on the schedule one tier after each successful year of teaching (recommended for contract renewal through professional evaluations). Professional Educators will advance to different levels of the Compensation Schedule or be eligible to receive a stipend based on a positive evaluation and the attainment of Professional Development points provided funds are available as determined by the District. The level of points required are outlined within each level.

\begin{tabular}{|c|c|c|c|}
\hline Grandfathered & Yearly Stipend & $\begin{array}{c}\text { Compensation Level } \\
\text { Increase } \\
\$ 0\end{array}$ & Level 6+ Requirements \\
\hline \multicolumn{2}{|c|}{$\$ 650$} & Over $\$ 71,000$ & \multirow{6}{*}{$\begin{array}{l}\text { While on Level } 6 \text {, teachers will move vertically on the schedule } \\
\text { one tier after each successful year of teaching (recommended } \\
\text { for contract renewal) Teachers must earn } 6 \text { approved } \\
\text { Professional Development Points to move to } 6 \text { C. } \\
\text { Teachers in tier } 6 \text { C and those who have been grandfathered } \\
\text { at their old salary must earn a minimum of } 3 \text { Professional } \\
\text { Development Points annually and be a teacher in good } \\
\text { standing to earn the Yearly Stipend. }\end{array}$} \\
\hline Level 6 & $\begin{array}{c}\text { Alternate Year(s) } \\
\text { Stipend }\end{array}$ & $\begin{array}{c}\text { Compensation Level } \\
\text { Increase } \\
\$ 1,200\end{array}$ & \\
\hline $6 \mathrm{C}$ & $\$ 650$ & $\$ 71,000$ & \\
\hline $6 \mathrm{~B}$ & & $\$ 69,800$ & \\
\hline $6 \mathrm{~A}$ & & $\$ 68,600$ & \\
\hline \multicolumn{3}{|c|}{$\begin{array}{l}\text { Level } 5 \text { to Level } 6 \\
\text { Increase } \\
\$ 3,000\end{array}$} & \\
\hline & & & \multirow{7}{*}{$\begin{array}{l}\text { While on Level 5, teachers will move vertically on the schedule } \\
\text { one tier after each successful year of teaching (recommended } \\
\text { for contract renewal) Teachers must have } 18 \text { approved } \\
\text { Professional Development Points to move on to Level } 6 \text {. } \\
\\
\text { Teachers initially placed at Level } 5 \mathrm{C} \text { may move to Level } 6 \mathrm{~A} \\
\text { after } 1 \text { year if they earn } 12 \text { approved Professional } \\
\text { Development points. If not, in year two they shall receive the } \\
\text { Alternate Year Stipend at the end of their second year and } \\
\text { every year after if they are a teacher in good standing until } 12 \\
\text { approved Professional Development points have been earned. }\end{array}$} \\
\hline & & & \\
\hline Level 5 & $\begin{array}{c}\text { Alternate Year(s) } \\
\text { Stipend }\end{array}$ & $\begin{array}{c}\text { Compensation Level } \\
\text { Increase } \\
\$ 1,200\end{array}$ & \\
\hline $5 \mathrm{C}$ & $\$ 650$ & $\$ 65,600$ & \\
\hline $5 B$ & & $\$ 64,400$ & \\
\hline $5 \mathrm{~A}$ & & $\$ 63,200$ & \\
\hline \multicolumn{3}{|c|}{$\begin{array}{l}\text { Level } 4 \text { to Level } 5 \\
\text { Increase } \\
\$ 3,000\end{array}$} & \\
\hline & & & Level 4 Requirements \\
\hline Level 4 & \begin{tabular}{|c} 
Alternate Year(s) \\
Stipend
\end{tabular} & $\begin{array}{c}\text { Compensation Level } \\
\text { Increase } \\
\$ 1,200\end{array}$ & \multirow{4}{*}{$\begin{array}{l}\text { While on Level 4, teachers will move vertically on the schedule } \\
\text { one tier after each successful year of teaching (recommended } \\
\text { for contract renewal) Teachers must earn } 18 \text { approved } \\
\text { Professional Development Points and must have a master's } \\
\text { degree to move on to Level } 5 .\end{array}$} \\
\hline $4 \mathrm{C}$ & $\$ 650$ & $\$ 60,200$ & \\
\hline $4 \mathrm{~B}$ & & $\$ 59,000$ & \\
\hline $4 \mathrm{~A}$ & & $\$ 57,800$ & \\
\hline
\end{tabular}




\begin{tabular}{|c|c|c|c|}
\hline \multicolumn{3}{|c|}{$\begin{array}{l}\text { Level } 3 \text { to Level } 4 \\
\text { Increase } \\
\$ 3,000 \\
\end{array}$} & \multirow{2}{*}{$\begin{array}{l}\text { Teachers initially placed at Level } 4 \text { C may move to Level } 5 \mathrm{~A} \\
\text { after } 1 \text { year if they earn } 12 \text { approved Professional } \\
\text { Development points. If not, in year two they shall receive the } \\
\text { Alternate Year Stipend at the end of their second year and } \\
\text { every year after if they are a teacher in good standing until } 12 \\
\text { approved Professional Development points have been } \\
\text { earned. }\end{array}$} \\
\hline & & & \\
\hline & & & Level 3 Requirements \\
\hline & & & \multirow{7}{*}{$\begin{array}{l}\text { While on Level 3, teachers will move vertically on the schedule } \\
\text { one tier after each successful year of teaching (recommended } \\
\text { for contract renewal) Teachers must earn } 18 \text { approved } \\
\text { Professional Development Points to move on to Level } 4 . \\
\text { Teachers initially placed at Level } 3 \mathrm{C} \text { may move to Level } 4 \mathrm{~A} \\
\text { after } 1 \text { year if they earn } 12 \text { approved Professional } \\
\text { Development points. If not, in year two they shall receive the } \\
\text { Alternate Year Stipend at the end of their second year and } \\
\text { every year after if they are a teacher in good standing until } 12 \\
\text { approved Professional Development points have been earned. }\end{array}$} \\
\hline Level 3 & $\begin{array}{l}\text { Alternate Year(s) } \\
\text { Stipend }\end{array}$ & $\begin{array}{c}\text { Compensation Level } \\
\text { Increase } \\
\$ 1,200\end{array}$ & \\
\hline $3 C$ & $\$ 650$ & $\$ 54,800$ & \\
\hline $3 \mathrm{~B}$ & & $\$ 53,600$ & \\
\hline $3 \mathrm{~A}$ & & $\$ 52,400$ & \\
\hline \multicolumn{3}{|c|}{$\begin{array}{l}\text { Level } 2 \text { to Level } 3 \\
\text { Increase } \$ 3,000\end{array}$} & \\
\hline & & & \\
\hline & & & Level 2 Requirements \\
\hline & & & \multirow{6}{*}{$\begin{array}{l}\text { While on Level 2, teachers will move vertically on the schedule } \\
\text { one tier after each successful year of teaching (recommended } \\
\text { for contract renewal). Teachers must earn } 18 \text { approved } \\
\text { Professional Development Points to move on to Level } 3 . \\
\text { Teachers initially placed at Level } 2 \text { C may move to Level } 3 \mathrm{~A} \\
\text { after } 1 \text { year if they earn } 12 \text { approved Professional } \\
\text { Development points. If not, in year two they shall receive the } \\
\text { Alternate Year Stipend at the end of their second year and } \\
\text { every year after if they are a teacher in good standing until } 12 \\
\text { approved Professional Development points have been earned. }\end{array}$} \\
\hline Level 2 & $\begin{array}{l}\text { Alternate Year(s) } \\
\text { Stipend }\end{array}$ & $\begin{array}{c}\text { Compensation Level } \\
\text { Increase } \\
\$ 1,200 \\
\end{array}$ & \\
\hline $2 \mathrm{C}$ & $\$ 650$ & $\$ 49,400$ & \\
\hline $2 B$ & & $\$ 48,200$ & \\
\hline $2 \mathrm{~A}$ & & $\$ 47,000$ & \\
\hline \multicolumn{3}{|c|}{$\begin{array}{l}\text { Level } 1 \text { to Level } 2 \\
\text { Increase } \$ 3,000\end{array}$} & \\
\hline & & & \multirow{8}{*}{$\begin{array}{l}\text { Level } 1 \text { Requirements } \\
\text { While on Level 1, teachers will move vertically on the schedule } \\
\text { one tier after each successful year of teaching (recommended } \\
\text { for contract renewal). Teachers must earn } 18 \text { approved } \\
\text { Professional Development Points to move on to Level } 2 \text {. } \\
\text { Teachers initially placed at Level 1E may move to Level 2A } \\
\text { after } 1 \text { year if they earn } 12 \text { approved Professional } \\
\text { Development points. If not, in year two they shall receive the } \\
\text { Alternate Year Stipend at the end of their second year and } \\
\text { every year after if they are a teacher in good standing until } 12 \\
\text { approved Professional Development points have been earned. }\end{array}$} \\
\hline Level 1 & $\begin{array}{c}\text { Alternate Year(s) } \\
\text { Stipend }\end{array}$ & $\begin{array}{c}\text { Compensation Level } \\
\text { Increase } \$ 1,000\end{array}$ & \\
\hline $1 \mathrm{E}$ & $\$ 650$ & $\$ 44,000$ & \\
\hline $1 D$ & & $\$ 43,000$ & \\
\hline $1 C$ & & $\$ 42,000$ & \\
\hline $1 B$ & & $\$ 41,000$ & \\
\hline $1 \mathrm{~A}$ & & $\$ 40,000$ & \\
\hline \multicolumn{3}{|c|}{$\begin{array}{l}\text { Level } 1 \text { to Level } 2 \\
\text { Increase } \\
\$ 3,000\end{array}$} & \\
\hline
\end{tabular}




\section{How can a teacher earn Professional Development Points?}

- Professional Development Points are calculated based on the amount of time, rigor and relevance of the professional development.

- Professional Development Points will be awarded if the Professional Development has been approved by the district. Approval of Professional Development Points occurs by submitting one of the following forms:

- The Mosinee School District Professional Development Point Request Form for graduate credit

- The Mosinee School District Professional Development Point Request Form for undergraduate credit

- The Mosinee School District Professional Development Point Request Form for locally provided or self-directed professional development

\begin{tabular}{|l|}
\hline 1 Professional Development Points $=10$ hours of Professional Development \\
\hline 3 Professional Development Points $=1$ Credit $=30$ Hours of Professional Development \\
\hline 6 Professional Development Points $=2$ Credits $=60$ Hours of Professional Development \\
\hline 9 Professional Development Points $=3$ Credits $=90$ Hours of Professional Development \\
\hline 12 Professional Development Points $=4$ Credits $=120$ Hours of Professional Development \\
\hline 15 Professional Development Points $=5$ Credits $=150$ Hours of Professional Development \\
\hline 18 Professional Development Points $=6$ Credits $=180$ Hours of Professional Development \\
\hline
\end{tabular}

- Professional Development Points must be earned during non-contracted time or during a personal day.

- Professional Development Points will be calculated for changes in compensation in the following manner: When you are ready to move to the next level you are required to turn in your documentation of approved Professional Growth by April 1 so that your correct contract for the following year can be issued to you by June 1.

- Professional Development Points earned will not be carried over from level to level.

- Initial placement in the compensation model will occur at the discretion of the Administration.

\section{What is a stipend?}

- Stipends are not part of the individual teacher's contract but would be provided as a nonrecurring supplemental pay.

- During the 2015-2016 school year, a one time, up to $\$ 650.00$ stipend will be paid to employees on the first pay roll (August 28,2015 ) to those employees who would have had less than an increase of $\$ 650.00$ during the crossover to the new Compensation System.

- In subsequent years, stipends may be earned by Professional Educators at the top tier of each level if they have not achieved the Professional Development points needed to move up to the next level. During this time, if the teacher has a positive evaluation (recommended for contract renewal) and is not on a Plan of Improvement they will be eligible to receive the stipend provided funds are available as determined by the district. Stipends would not be part of the individual teacher's contract, but would be provided as non-recurring supplemental pay. 


\section{Appendix G: Monona Grove School District Career Ladder Framework}

\begin{tabular}{|c|c|c|c|}
\hline Career Ladder Steps & Performance Expectations & \begin{tabular}{|l} 
Advancement \\
Process
\end{tabular} & $\begin{array}{l}\text { Salary } \\
\text { Range }\end{array}$ \\
\hline $\begin{array}{l}\text { Distinguished Teacher } \\
\text { Entry Criteria: } \\
\text { - Wisconsin Professional Educator } \\
\text { or Master Educator License } \\
\text { - Pre-approved Master's or } \\
\text { Doctorate Degree } \\
\text { - } 11 \text { years of 4K-12 teaching } \\
\text { experience } \\
\text { - Evidence of Advanced- level } \\
\text { teaching practice } \\
\text { - Formal and Informal Leadership }\end{array}$ & $\begin{array}{l}\text { Performance Expectations include: } \\
\text { - Maintains Wisconsin Professional Educator } \\
\text { - License or Master Educator License } \\
\text { - Actively participates and/or leads in district- } \\
\text { required professional development } \\
\text { - Maintains Monona Grove PD Plan } \\
\text { - Collaborates with colleagues } \\
\text { - Maintains Advanced Teaching Practices } \\
\text { - } \text { - For time (see rubric) } \\
\text { - }\end{array}$ & $\begin{array}{l}\text { Review Committee } \\
\text { recommendation to } \\
\text { Superintendent }\end{array}$ & $\begin{array}{l}\text { To be } \\
\text { Determined } \\
\text { prior to } \\
\text { 2016-2017 } \\
\text { school year. }\end{array}$ \\
\hline $\begin{array}{l}\text { Professional Leader Teacher } \\
\text { Entry Criteria: } \\
\text { - Wisconsin Professional Educator } \\
\text { License or Master } \\
\text { - Educator License } \\
\text { - Pre-approved Master's Degree } \\
\text { - } 8 \text { years of } 4 \mathrm{~K}-12 \text { teaching } \\
\text { experience } \\
\text { - Evidence of Advanced- level } \\
\text { teaching practice } \\
\text { - Formal or Informal Leadership }\end{array}$ & $\begin{array}{l}\text { Performance Expectations include: } \\
\text { - Maintains Wisconsin Professional Educator } \\
\text { - License or Master Educator License } \\
\text { - } \text { requiredy participates and/or leads in district- } \\
\text { - Maintains Mononona Grove PD Plan } \\
\text { - Collaborates with colleagues } \\
\text { - Maintains Advanced Teaching Practices } \\
\text { over time (see rubric) } \\
\text { - Formal or informal leadership }\end{array}$ & $\begin{array}{l}\text { Review Committee } \\
\text { recommendation to } \\
\text { Superintendent }\end{array}$ & $\begin{array}{l}\text { To be } \\
\text { Determined } \\
\text { prior to } \\
2016-2017 \\
\text { school year. }\end{array}$ \\
\hline $\begin{array}{l}\text { Professional Teacher } \\
\text { Minimum Criteria: } \\
\text { - Wisconsin Professional Educator } \\
\text { License } \\
\text { - } 5 \text { years of } 4 \mathrm{~K}-12 \text { teaching } \\
\text { experience }\end{array}$ & $\begin{array}{l}\text { Performance Expectations include: } \\
\text { - Maintains Wisconsin Professional Educator } \\
\text { - License } \\
\text { - Actively participates and/or leads in district- } \\
\text { required professional development } \\
\text { - Maintains Monona Grove PD Plan } \\
\text { - Collaborates with colleagues } \\
\text { - Maintains high standards of Teaching } \\
\text { - Practices over time (Danielson Framework) }\end{array}$ & $\begin{array}{l}\text { Administrative } \\
\text { recommendation to } \\
\text { Superintendent }\end{array}$ & $\begin{array}{l}\$ 42,000- \\
\$ 67,000\end{array}$ \\
\hline $\begin{array}{l}\text { Post-Mentorship } \\
\text { Minimum Criteria: } \\
\text { - Wisconsin Initial Educator } \\
\text { License } \\
\text { - } 2-4 \text { years of } 4 \mathrm{~K}-12 \text { teaching } \\
\text { experience }\end{array}$ & $\begin{array}{l}\text { Performance Expectations include: } \\
\text { - Completes PDP and obtains Wisconsin } \\
\text { - Professional Educator License } \\
\text { - Actively participates in district-required } \\
\text { - professional development } \\
\text { - Maintains Monona Grove PD Plan } \\
\text { - Collaborates with colleagues } \\
\text { - Satisfactory performance evaluations }\end{array}$ & \begin{tabular}{|l} 
Administrative \\
recommendation to \\
Superintendent
\end{tabular} & $\begin{array}{l}\$ 40,000- \\
\$ 47,000\end{array}$ \\
\hline $\begin{array}{l}\text { Mentorship } \\
\text { Minimum Criteria: } \\
\text { - Wisconsin Initial Educator } \\
\text { License } \\
\text { - } 0 \text {-1 year of } 4 \mathrm{~K}-12 \text { teaching } \\
\text { experience }\end{array}$ & $\begin{array}{l}\text { Performance Expectations include: } \\
\text { - Maintains Wisconsin Initial Educator License } \\
\text { - Actively participates in MGSD New Teacher } \\
\text { Mentor Program } \\
\text { - Actively participates in district-required } \\
\text { professional development } \\
\text { - Maintains Monona Grove PD Plan } \\
\text { - Collaborates with colleagues } \\
\text { - Satisfactory performance evaluations }\end{array}$ & \begin{tabular}{|l|} 
Initial hiring \\
recommendation
\end{tabular} & $\begin{array}{l}\$ 38,000- \\
\$ 44,000\end{array}$ \\
\hline
\end{tabular}




\section{Definitions}

Mentorship Teacher. The Mentorship Teacher holds a Wisconsin Initial Educator License. This teacher is new to the profession and actively participates in the district induction program to improve his or her teaching practice for the benefit of student learning. The Mentorship Teacher is expected to participate in collaborative work with colleagues, and participate in professional development. The Mentorship Teacher is not expected to assume formal or informal leadership roles.

Post-Mentorship Teacher. The Post-Mentorship Teacher holds a Wisconsin Initial Educator License. This teacher is an early-career teacher who has successfully completed the district induction program and is engaging in continuous improvement of his/her teaching practice. The Post-Mentorship Teacher also develops a Monona Grove Professional Development Plan (MGPD) that includes requirements for a Wisconsin Professional Educator license. The Post-Mentorship Teacher participates in collaborative work with colleagues and professional development, and may choose to assume leadership responsibilities.

Professional Teacher. The Professional Teacher holds and maintains a Wisconsin Professional Educator license. This teacher consistently meets high performance standards for classroom teaching, collaborative work with colleagues, professional development (including the MGPD), and other professional responsibilities. The Professional Teacher is encouraged to take on leadership responsibilities.

Professional Leader Teacher. The Professional Leader Teacher holds and maintains a Wisconsin Professional Educator or Master Educator license. This teacher demonstrates clear, convincing, and consistent evidence of advanced standards of classroom teaching practice, collaboration with colleagues, and formal or informal leadership as defined in the Professional Advancement Rubric. This teacher also maintains such practice over time. This teacher participates in professional development including completing the MGPD.

Distinguished Teacher. The Professional Leader Teacher holds and maintains a Wisconsin Professional Educator or Master Educator license. This teacher demonstrates clear, convincing, and consistent evidence of master educator-level standards of classroom teaching practice, collaboration with colleagues, and formal and informal leadership as defined in the Professional Advancement Rubric. This teacher also maintains such practice over time. This teacher participates in professional development including completing the MGPD.

Teacher Leader Positions. Teacher Leader positions are specific roles in the district that may be in addition to or in lieu of a classroom teaching assignment. Currently these roles would include positions such as Full Release Mentor, Teacher on Special Assignment (TOSA), and MG21 Lead Teacher. In the future additional Teacher Leader roles for classroom teachers may emerge, such as content- area curriculum coordinator. Teacher Leader roles are not permanent assignments and service in one of these roles may be limited to a range of years (e.g. The Full Release Mentor serves in that role for approximately five years before returning to the classroom. Other roles may serve 2-5 years.)

MGSD Professional Development Plan (MGPD). Every Monona Grove School District teacher shall develop and carry out an individual professional development plan consistent with the Wisconsin Educator Effectiveness Professional Practice Goals Process (e.g., the Effectiveness Plan) and Wisconsin Teacher License renewal. The MGPD should be developed and periodically reviewed in consultation with the evaluating administrator and with counsel and advice from colleagues, instructional coaches, teacher leaders, and/or distinguished teachers. The MGSD shall establish a program of training for teachers to develop and revise their MGPD's and also for evaluating administrators and others to consult, counsel, and advise in their development and revision. 


\section{Appendix H: Elmbrook School District Total Reward System Summary}

\section{Career Pathway}

\begin{tabular}{|c|c|c|}
\hline Career Level & Description & Pay Range \\
\hline Developing: Domain of Self & $\begin{array}{ll}\text { - } & \text { Initial educators, within 1-5 years } \\
\text { - } & \text { Focus developing classroom teaching skills }\end{array}$ & $\begin{array}{l}\$ 42,326- \\
\$ 48,674\end{array}$ \\
\hline Establishing: Domain of PLC & $\begin{array}{l}\text { - } \quad \text { Novice teachers within 4-10 years of experience. } \\
\text { - Developed instructional practices with focus growing from } \\
\text { self to team, gaining collaboration, shared decision-making } \\
\text { and leadership skills. }\end{array}$ & $\begin{array}{l}\$ 46,741- \\
\$ 56,089\end{array}$ \\
\hline Mastery 1: Domain of School & $\begin{array}{l}\text { - } \quad \text { Teachers with 8-15 years of experience. } \\
\text { - } \quad \text { Evidence of ongoing formal education (i.e., district } \\
\text { - } \quad \text { Recognnized building leader with influence beyond grade- } \\
\text { level peers. } \\
\text { - } \quad \text { May be coach, mentor, grade-level leader or department } \\
\text { chair. }\end{array}$ & $\begin{array}{l}\$ 52,817- \\
\$ 63,381\end{array}$ \\
\hline Mastery 2: Domain of District & $\begin{array}{l}\text { - } \quad \text { About } 10 \text { or more years of experience, with district } \\
\text { approved masters or certifications. } \\
\text { - } \quad \text { Demonstrates influence at district level through committee } \\
\text { work. } \\
\text { - May be teaching and learning specialists or National Board } \\
\text { Certified. }\end{array}$ & $\begin{array}{l}\$ 58,357- \\
72,947\end{array}$ \\
\hline Exemplary: Domain of Region & $\begin{array}{l}\text { - About } 15 \text { or more years of experience, with multiple } \\
\text { advanced degrees and/or certifications. } \\
\text { - Demonstrates influence in the region or state through } \\
\text { associations, conference presentations, grant writing, etc. }\end{array}$ & $\begin{array}{l}\$ 64,510- \\
\$ 83,863\end{array}$ \\
\hline
\end{tabular}

\section{Pay Overview}

\begin{tabular}{|c|c|c|}
\hline Type of Increase & Definition & Influencing Factors \\
\hline Base Wage & $\begin{array}{l}\text { - Permanent addition to employees' } \\
\text { base salary. }\end{array}$ & $\begin{array}{l}\text { 1. Performance appraisal rating - Educator } \\
\text { Effectiveness rating or short-cycle rating } \\
\text { 2. Career Ladder Progression- education, } \\
\text { professional learning, continuous } \\
\text { improvement, collaboration and leadership }\end{array}$ \\
\hline Stipend & $\begin{array}{l}\text { - Remains in place for duration of time } \\
\text { employee continuous serving in } \\
\text { recognized capacity. } \\
\text { - Do not increase base wage and ends } \\
\text { when circumstance no longer exists. }\end{array}$ & $\begin{array}{l}\text { 1. Critical shortage area } \\
\text { 2. Extra duty contracts - compensation for } \\
\text { extra duty (e.g., coaching, department } \\
\text { chair, grade-level leader) not included in } \\
\text { the new plan, but may be going forward }\end{array}$ \\
\hline Bonus & $\begin{array}{l}\text { - One time payments to acknowledge a } \\
\text { significant performance or contribution } \\
\text { - Bonuses do not increase base wage } \\
\text { and do not carry over annually. }\end{array}$ & $\begin{array}{l}\text { 1. Professional Learning } \\
\text { 2. School report card }\end{array}$ \\
\hline
\end{tabular}


Copyright (C) 2016 by Steven M. Kimball, Herbert G. Heneman, III., Robin Worth, Jessica Arrigoni, and Daniel Marlin

All rights reserved.

Readers may make verbatim copies of this document for noncommercial purposes by any means, provided that the above copyright notice appears on all copies. WCER working papers are available on the Internet at http://www.wcer.wisc.edu/publications/working-papers.

The authors gratefully acknowledge Sarah Archibald and Brad Carl for their feedback on prior versions of this paper, and Karen Faster for her careful editing of the final draft. 